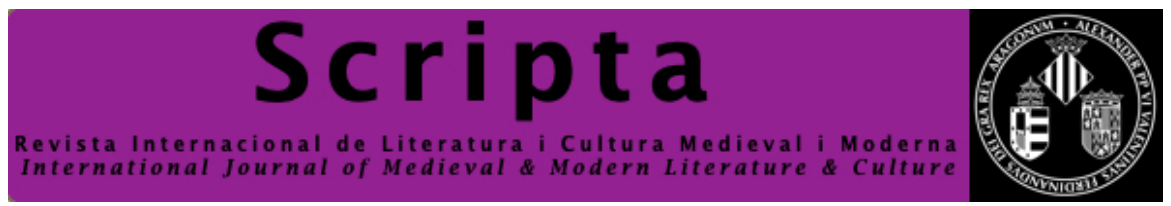

\title{
El procés contra el mulat Amador de Molina per sodomia, del 1588
}

\author{
1588’s sodomy process against mulatto Amador de Molina
}

\author{
Jacob Mompó Navarro \\ jacobmompo@gmail.com
}

Universitat Catòlica de València

\begin{abstract}
Resum: La sodomia ha estat perseguida al llarg de la història europea pels tribunals civils i eclesiàstics. A més, a partir de l'any 1524 la Inquisició obtingué jurisdicció plena per jutjar la sodomia als territoris d'Aragó, Catalunya i València. Amador de Molina ja havia sigut jutjat i condemnat a Múrcia, des d'on va arribar, desterrat, a la localitat d'Ontinyent. Denunciat per l'estupre d'un menor, el Tribunal de la Inquisició de València es va mostrar implacable. Junt amb la transcripció del procés, aportem en aquest article una relació general d'alguns dels treballs més significatius en l'estudi de la Inquisició i la repressió sexual, i un esbós dels marcs doctrinals i legals del pecat-delicte de sodomia.
\end{abstract}

Paraules clau: sodomia, homosexualitat, pecat nefand, crim, Inquisició, repressió sexual.

Abstract: Throughout European history, sodomy has been pursued by civil and ecclesiastical courts. In addition, from 1524 on, the Inquisition obtained jurisdiction to judge sodomy in the territories of Aragon, Catalonia and Valencia. Amador de Molina had been judged and sentenced in Murcia, from where he arrived, exiled, in the village of Ontinyent. Denounced by the rape of a minor, the Court of the Inquisition of Valencia was relentless. Along with the transcription of the process, in this article we provide a general relation of some of the most significant works in the study of the Inquisition and sexual repression, and an outline of the doctrinal and legal frameworks of the sin-crime of sodomy.

Keywords: sodomy, homosexuality, nefarious sin, crime, Inquisition, sexual repression. 


\section{Introducció}

Els estudis sobre la Inquisició, en general, van viure un punt àlgid durant els primers anys de la transició democràtica espanyola; sobretot, a partir del curs d'estiu organitzat per la Universidad Menéndez y Pelayo a Santander l'any 1976. Des d'aquell any i fins al 1986, els estudis inquisitorials van veure una embranzida que es va materialitzar en nombroses publicacions, congresos i, fins i tot, la creació de dues institucions amb voluntat historiogràfica entorn la Inquisició: el Centro de Estudios Inquisitoriales i el Instituto de Historia de la Inquisición. Ricardo García Cárcel (1996) es lamentava en la dècada dels 90 de la pèrdua de vitalitat d'aquella onada historiogràfica dels anys 80 .

Molt abans d'aquell any 1976, però, l'estadounidenc Henry Charles Lea (1906-08) s'esforçava a desvincular el seu treball de la llegenda negra que s'havia teixit, principalment, als països protestants envers la Inquisició espanyola. ${ }^{1}$ Segons l'hispanista i estudiós de la Inquisició Henry Kamen (1981), l’obra de Lea, malgrat el temps transcorregut des de la seua publicació, «llegó a conclusiones que nunca fuero refutadas, y es difícil que sean superadas» (Kamen, 1981: 666). Amb tot, el mateix autor suara citat, abans de l'esmentat curs d'estiu de Santander, aportava el seu granet de sorra als estudis sobre la Inquisició amb la publicació de l'obra La Inquisición española (Kamen, 1967). Durant la dècada anterior, també havia publicat Arthur Turberville la seua La Inquisición española (Turberville, 1954). Ara bé, pel que fa als autors espanyols, la trobada de Santander va suposar l’inici d'una nova historiografia sobre la Inquisició que superava la tradicional bipolarització ideològica entre el corrent conservador, amb Menéndez Pelayo ${ }^{2}$ com a màxim exponent, i la línia progressista, adscrita al corrent iniciat per Juan Antonio Llorente, ${ }^{3}$ (García Cárcel, 1996: 33). Els primers anys de la Transició, doncs, van propiciar l'aparició de nombroses obres de caire historiogràfic entorn la Inquisició, tant de carácter general, ${ }^{4} \mathrm{com}$ enfocades a algun territori en concret o Tribunal específic. ${ }^{5}$

1 Una aportació sobre la formació de la llegenda negra al capítol «The invention of The Inquisition», a dins l’obra d'Edward Peters (1988: 122-154). Vegeu també, en aquest mateix sentit, el capítol «Inventando la Inquisición», de Henry Kamen (2005: 294-308).

2 La postura de Menéndez Pelayo contra els heterodoxos, la defensa de la religió catòlica i la justificació de l'existència de la Inquisició, a l'obra Historia de los heterodoxos españoles (1880-1881).

3 Va ser membre de l'aparell del Sant Ofici, per bé que els esdeveniments històrics i l'evolució del seu pensament polític i religiós el van dur a escriure, a l'exili francés, l'obra Histoire critique de l'Inquisition espagnole (1817-1818), especialment crítica amb la institució inquisitorial. La seua obra ha estat tradicionalment criticada, bé per les xifres de condemnats que aporta, bé pel seu posicionament liberal i afrancesat; entre els seus detractors, el mateix Menéndez Pelayo (Dufour, 1988).

4 Pel que fa a l'estudi general de la Inquisició, entre les obres que sorgiren d'aquella onada investigadora destaquem la publicació de les actes del Primer Simposio Internacional sobre la Inquisición, celebrat a Conca del 25 al 29 de setembre de 1978 (Pérez Villanueva, 1980); els tres volums de la Historia de la Inquisición en España y América, dirigida per Pérez Villanueva \& Escadell Bonet (1984); Inquisición española. Poder político y control social, de Bartolomé Bennassar (1984); Inquisición y control ideológico en la España del siglo XVI, de Virgilio Pinto Crespo (1983); La Inquisición, de Juan Blázquez Miguel (1988); o La Inquisición, de Ricardo García Cárcel (1990). Importantíssima també l'aportació de José Antonio Escudero López en diferents treballs com «Los orígenes del Consejo de la Suprema Inquisición» (1983), «Inquisición y estudios inquisitoriales» (1987), «La Inquisición española» (1986) o, més recent, el monogràfic Estudios sobre la Inquisición (2005), o La Inquisición (Escudero \& Birckel, 2004), entre d'altres.

5 Per a l'estudi de la Inquisició als territoris de la Corona d’Aragó, vegeu les aportacions de Ricardo García Cárcel, «La Inquisición en la Corona de Aragón» (1998); La otra Inquisición. Inquisición española en la Corona de Aragón, Navarra,

SCRIPTA, Revista internacional de literatura i cultura medieval i moderna, núm. 12/ desembre 2018/pp. 3470 ISSN: 2340 - 4841 doi:10.7203/SCRIPTA.12.13663 
No volem incidir en els motius que produïren la davallada posterior en la producció de materials historiogràfics de temàtica inquisitorial a què es referia García Cárcel (1996); més bé, considerem oportú en aquest article de fer menció d'aquells treballs que, dins l'interés general que provocava -i encara ho fa- la Inquisició, es van centrar en aspectes relatius a la repressió sexual. En aquest mateix sentit, prompte apareixien aportacions centrades en aquesta temàtica, en general, com el breu article del ja citat Henry Kamen, «Sexualidad e Inquisición» (1976); o el de Rafael Carrasco, «Herejía y sexualidad en el Siglo de Oro» (1985). Al mateix Carrasco devem l'article «Las torpezas nefandas» (1982). Igualment, Francisco Tomás i Valiente editava el monogràfic Sexo barroco y otras transgresiones premodernas, on aportava el seu article enfocat a la repressió de l'homosexualitat «El crimen y pecado contra natura» (1990). Més recents són els estudis sobre la repressió sexual de Federico Garza Carvajal, Butterflies wil burn: Prosecuting Sodomites in Early Modern Spain and Mexico (2003); o Cristian Berco, Sexual hirarchies, public status: Men, sodomy, and society in Spain's golden age (2007). Iñaki Bazán, per la seua banda, ofereix una panoràmica general sobre l'evolució de l'homofòbia a l'època medieval a l'article «La construcción del discurso homofóbico en la Europa cristiana medieval» (2007).

Una part, però, interessantíssima dels estudis sorgits entorn la repressió sexual està formada per obres amb un àmbit d'acció més reduït. Són aquells treballs que ens aporten una mirada més pròxima, focalitzats en territoris concrets. Aquest és el cas dels articles «Inquisición y sexualidad en el Reino de Granada en el siglo XVI» (García Fuentes, 1982) o «La sexualidad prohibida y el Tribunal de la Inquisición de Llerena» (Testón \& Hernández, 1988). Més recent és «"Meresce la pena ordinaria de muerte": Estudio de las denuncias por bestialismo en la Navarra del Antiguo Régimen» (Ruiz Astiz, 2017) o el treball centrat en la repressió sexual al Perú de Fernanda Molina, «Los sodomitas virreinales: entre sujetos jurídicos y especie» (Molina, 2010a), producte de la seua investigació doctoral No digno de nombrar. Prácticas sexuales probibidas en el virreinato del Perú (siglos XVIXVII) (2009). Pel que fa a la Corona d'Aragó, destaquen el capítol de Bartolomé Bennassar «El modelo sexual: La Inquisición de Aragón y la represión de los pecados “abominables”» (Bennassar, 1984: 295-320), «The repression of sexual behavior by the Aragonese Inquisition between 1560 and 1700» (Fernández, 1997) o el recent «Represión y uso socio-político de la sodomía en la Corona de Aragón en el siglo XVI» (Navarro Martínez, 2017).

Entre les aportacions pioneres en aquest àmbit i en territoris de la Corona d'Aragó resulten d'especial interés l'obra L'homosexualitat a Mallorca a l'edat mitjana, de Ramón Rosselló (1978) i les aportacions de Rafael Carrasco Inquisición y represión sexual en Valencia. Historia de los sodomitas. 1565-1785 (1986) i «Marginalidad sexual e Inquisición en la Valencia moderna» (1987). Poc després es publicava l'article «El delito de sodomía en la Valencia del siglo XVI» (Graullera, 1991). Enfocat als territoris

el País Vasco y Sicilia (Monter, 1992); o les apreciacions sobre el Principat i la seua situació després de la Contrareforma a The phoenix and the flame. Catalonia and the Counter Reformation (Kamen, 1993). Pel que fa al cas concret del Tribunal de València és indispensable, de nou, els treballs de Ricardo Garcia Cárcel Orígenes de la Inquisición española. El Tribunal de Valencia, 1478-1530 (1976) i Herejia y sociedad en el siglo ХИ. La Inquisición en Valencia, 1530-1609 (1980). En aquest mateix sentit, vegeu Inquisition and society in the Kingdom of Valencia, 1478-1834 (Haliczer, 1990). 
de la jurisdicció de l'Arquebisbat de Saragossa, «Imago Dei deturpatur: El pecado "nefando" o "contra natura" en el Arzobispado de Zaragoza (Siglos XV-XVI)» (Dotis Dolader, 2000). Finalment, per a l'estudi de la repressió sexual, en aquest cas emmarcat, principalment, a Catalunya, esdevé imprescindible Sodomites Catalans, de Jaume Riera i Sans (2014). Aquest treball de Riera i Sans i les obres esmentades de Rosselló (1978) i Carrasco (1986) són cabdals per a l'estudi de la repressió de l'homosexualitat als territoris de parla catalana. Rosselló esdevenia el pioner en abordar aquesta temàtica enfocada a Mallorca; poc després, Carrasco aportava el seu estudi circumscrit al Tribunal de la Inquisició de València. Sodomites Catalans se centra en el territori del Principat, per bé que aporta bastants casos jutjats a València i, també, a valencians. Totes tres obres ens aporten una visió fonamental per a l'estudi de la repressió sexual.

$\mathrm{Al}$ nostre article, però, no ens centrarem en l'activitat represora, en general, del Sant Ofici; tampoc en la repressió sexual, temàtiques aquestes a bastament treballades a les obres adés adduïdes. Dirigirem la nostra atenció a un únic subjecte de repressió sexual-també, segurament, racial-com va ser el mulat Amador de Molina, jutjat per sodomia i sentenciat pel Tribunal de la Inquisició de València l'any 1588. Abans, però, tractarem d'explicar succintament el delicte pel qual fou jutjat.

\section{La sodomia. Entre el pecat i el delicte}

Segons la tradició escolàstica, la finalitat de l'acte sexual és únicament la procreació de l'espècie; pot haver-hi plaer, en tant que estímul a la procreació, però l'objectiu del coit no pot ésser cap altre que la generació de nous individus. La còpula sense finalitat reproductora, amb l'única voluntat d’obtenció de plaer, era pecat de luxúria. Tenint en compte això, la tradició escolàstica medieval s'entestà a ordenar els pecats de luxúria en una mena d'escalafó. ${ }^{6}$ Són diverses les classificacions que es van fer, però la que va obtenir més fortuna és la de fra Tomàs d'Aquino, que va classificar sis espècies de luxúria, això és, de més lleu a més greu: la fornicació, l’adulteri, l’incest, l'estupre, el rapte i el vici contra natura. Especialment greu era aquest darrer, perquè, cercant l'obtenció del plaer, el luxuriós bandeja l'única finalitat legítima de l'acte sexual: la generació. Encara va dividir el pecat contra natura en diverses subespècies més, de les quals n'anomena tres, igualment per ordre creixent de gravetat: la masturbació, la bestialitat i el vici sodomític (Riera i Sans, 2014: 27-28). De classificacions dels pecats de luxúria n'hi hagué moltes, però totes coincidien a remarcar la gravetat de les relacions «contra natura». Eiximenis, per exemple, al Terç del Cristià englobava sota la definició de sodomia quatre espècies de pecats luxuriosos: la masturbació, la bestialitat, les relacions entre individus del mateix gènere $i$, finalment, les relacions contra natura entre persones de diferent sexe, «si entre hom e fembra no 's serva la manera natural» (Riera i Sans, 2014: 31).

6 Una descripció dels pecats de luxúria a Tomás y Valiente (1990: 33-55). En aquest mateix sentit, igualment interessants resulten l'apartat «Els marcs doctrinals» de Jaume Riera i Sans (2014: 24-41) i el capítol «El concepto de pecado nefando» de Carrasco (1986: 30-50). 
En qualsevol cas, malgrat que totes les ementades espècies de sodomia eren considerades igualment pecaminoses i detestables, les relacions homosexuals -també el bestialisme- representaven el més greu exponent del pecat de luxúria perquè, en paraules de Miguel Ángel Dotis:

No se trata de una mera fornicación extramatrimonial, de dolo o de ofensa a un sacramento: es Dios el ofendido directamente, sin intermediación ni paliativos, porque se altera su cosmogénesis, se perturba el orden natural -superior al social- y se interrumpe el sagrado eslabón -el alma- de la Creación divina (Dotis, 2000: 351).

Apreciacions com aquestes permeteren en ocasions la vinculació de la sodomia amb l'heretgia. ${ }^{7}$ D’altra banda, a més de la consideració teològica del pecat de luxúria, la sodomia constituïa jurídicament un delicte ${ }^{8}$ dualitat aquesta que té per fonament les aportacions del dret romà, el dret canònic medieval i la tradició religiosa (Molina, 2010a: 25-26) i que propiciaren que la sodomia esdevingués en un assumpte de fur mixt, perseguit pels tribunals eclesiàstics, però també pels civils, accentuant més la indentificació entre sodomia i heretgia (Molina, 2010b: 541). La justícia seglar, doncs, també perseguia durament la sodomia, en tant que delicte, i els sodomites eren considerats com a pertorbadors de l'ordre social; criminals, per tant, a més de pecadors. Segons Riera i Sans, «la doctrina cristiana que condemnava la sodomia inspirà les lleis que la condemnaven, però no és noble silenciar que la seva penalització fou assumida pels codis civils» (2014: 42). En aquest sentit, la pena imposada al delicte de sodomia pels diferents codis civils al llarg de la història de l'Occident cristià era la mort, generalment, a la foguera. Si Déu va castigar els habitants de Sodoma -també Gomorra- amb una pluja de sofre i foc (Gn, 19: 24), calia aplicar idèntica purga a aquells que practicaven el mateix pecat que -segons sembla- era habitual entre les gents d'aquelles dues ciutats bíbliques. El codi Justinià (de l'any 534, revalidat als territoris catalans al segle XII i recollit a les diferents compilacions del Corpus iuris civilis) ja contemplava la pena capital per als sodomites, $\mathrm{i}$ la mateixa sort els hi era reservada a les posteriors lleis visigòtiques (Riera i Sans, 2014: 43-44). La pena era la mateixa a tots els territoris peninsulars i, en el cas concret del regne de València, els furs marcaven el camí: «Heretges, e sodomites, sien cremats» (Carrasco, 1986: 12; nota 4).

Ara bé, tot i que que la Inquisició era un tribunal que jutjava delictes de caire doctrinal, i malgrat que la sodomia, tot i no ser un afer extríctament doctrinal, estava, com hem vist, considerada com un dels més greus pecats, el delicte sodomític no sempre va recaure dins els límits jurisdiccionals de la Inquisició; i, dins l'organització del Sant Ofici, tampoc tots els tribunals territorials de la Inquisició tenien jurisdicció plena per jutjar la sodomia. Si bé és cert que, en gener de 1505, Ferran el Catòlic incloïa la sodomia en l'àmbit jurisdiccional de la Inquisició, en 1509 quedava sense efecte aquesta

\footnotetext{
7 Més clara sembla la vinculació de la bigàmia i la sol licitació amb l'heretgia, en tant que suposaven un atac als sagraments del matrimoni i la confessió. Sobre la possible vinculació de la sodomia amb l'heretgia, especialment interessant és l'article de Fernanda Molina «La herejización de la sodomía en la sociedad moderna. Consideraciones teológicas y praxis inquisitorial» (Molina, 2010b).

8 Per al tractament de la sodomia dins l'àmbit jurídic dels períodes medieval i modern vegeu l'apartat «Els marcs legals» (Riera i Sans, 2014: 41-75). Una visió sobre la dualitat pecat-delicte a Motis Dolader (2000, 345-348); també, a Molina (2010a: 24-29).
} 
pragmàtica, perquè un decret del Consejo de la Suprema Inquisición ordenava que els inquisidors no havien d'actuar contra els sodomites, sempre que «otras cosas no hay[a $]^{9}$ en ello que sepan herejía» (Carrasco, 1986: 11). No és fins l'any 1524 que, amb un breu del papa Climent vII, s'autoritzava el Sant Ofici a jutjar casos de sodomia, i només als territoris del principat de Catalunya i els regnes de València i Aragó. En el cas de Mallorca, resulta explicativa la nota que aporta Carrasco d'un document inquisitorial que diu: «En las Inquisiciones de la Corona de Aragón, Zaragoza, Valencia, Barcelona, y no en Mallorca, con ser de la Corona, por no estar en uso, se conoce del pecado nefando por Breve de Clemente vII» (Carrasco, 1986: 12; nota 5).

No obstant això, en 1724, el Tribunal de la Inquisició de Mallorca jutjava Cosme Mut pel delicte de sodomia. En aquest cas, però, l'acusat era prevere i beneficiat de la catedral de Palma i, a més d'ésser jutjat per «perpetrar el fehíssimo delicto de sodomía, ha dicho y enseñado diferentes vezes proposiciones temerarias, herróneas, heréticas y escandalosas que le hazen sospechoso vehementemente en la Fe». ${ }^{10}$ Es tractava d'allò que hem comentat més amunt de no jutjar els sodomites si no és que hi hagués quelcom més «que sepa a herejía». Abans d'aquest cas, l'any 1634, el Tribunal de Mallorca jutjava Pere Andrés Coll per haver comés el nefand delicte de sodomia amb un esclau a una garita de la muralla. Pere i l'esclau van ser detinguts per la justícia civil, però el Tribunal de la Inquisició de Mallorca demanava el trasllat dels reus sota la seua jurisdicció amb els següents termes: «Supplica a V. S., sea servido entregar los dichos esclavo y Coll en poder del Sancto Tribunal, a quien toca conocer y castigar al dicho delicto». ${ }^{11}$ El problema jurisdiccional, en aquest cas, no es basava en el delicte comés, sinó en el fet que l'esclau era propietat de Pere Súnyer, algutzir del Sant Ofici i, per tant, «por ser esclavo de official del dicho Sancto Tribunal». ${ }^{12}$

Deixarem de banda els motius d'aquestes divergències jurisdiccionals entre els diferents tribunals territorials de la Inquisició. ${ }^{13}$ Amb tot, els sodomites no estaven lliures als territoris on la Inquisició no tenia jurisdicció sobre l'esmentat delicte; ja hem dit que eren perseguits per la justícia reial, la qual, d'altra banda, oferia menys garanties processals que no la Inquisició. Ara bé, on el Sant Ofici

9 El canvi d’indicatiu a subjuntiu és nostre.

10 Procés de Fe contra Cosme Mut, AHN, InQuisición, 1715, Exp. 6: Img. 3.

11 Procés de Fe contra Pere Andrés Coll, AHN, INQuisició, 1699, Exp. 22: Img. 5.

12 Ibídem: Img. 6.

13 Jaume Riera i Sans apunta a interesos particulars de Carles I per intentar resoldre d'inmediat «el procés de naturalesa política contra Sancho de la Cavalleria, jurista de Saragossa, que estava encallat per qüestions de procediment, i en concret perquè els furs d'Aragó no consentien l'ús de la tortura judicial» (2014: 51). Segons Fernanda Molina, parafrassejant Monter (1992: 328), aquesta disposició papal va ser la resposta a la denúncia del mateix Sancho de la Cavalleria a la Suprema, denunciant els inquisidors per processar-lo per sodomia sense tindre-hi competències (Molina, 2010b: 543). En canvi, Carrasco afirma que la concessió de competències sobre el delicte de sodomia als inquisidors aragonesos, valencians i catalans permetia, efectivament, l'aplicació de la tortura, tal com feia sobre els sodomites la justícia civil castellana; però, llegint entre línies el breu de Clement vII, arriba a la conclusió que els sodomites infidels a què es refereix no són altres que els moriscos, batejats a la força durant les Germanies (Carrasco, 1986: 57-58). 
hi tenia jurisdicció, els homosexuals podien caure en mans d'ambdues justícies, tant la reial com la inquisitorial. En el cas que ens pertoca, veurem com Amador de Molina ja havia estat pres a Múrcia, segons els testimonis, acusat de sodomia. Algun testimoni afirma que no van poder provarli el delicte, d'altres que havia sigut desterrat; cap d'ells diu que el tribunal que el va jutjar fóra el de la Inquisició. És probable que el jutgés la justícia civil o l'eclesiàstica, per bé que no ho podem assegurar.

El Tribunal de València, en canvi, sí que tenia jurisdicció plena per jutjar la sodomia, fins i tot quan no hi hagués mostres d'heretgia, i es va mostrar implacable amb Amador al llarg del seu procés. Segons Carrasco, la durada d'un procés per sodomia solia ser d'un any de mitjana, poc més o menys (1986: 54). Però, per exemple, el procés a fra Joan Nolasco, mercedari, provincial de la Província de València va durar 10 anys; o el de Gesualdo Felices, noble, nou anys (Carrasco, 1986: 13). Ara bé, la majoria dels acusats eren d'extracció social humil i els processos, com el d'Amador, acabaven ràpidament. En aquest sentit, el cas d'Amador es va solventar en mig any, des del seu ingrés a la presó fins l'aplicació final de la sentència.

Si bandejem la durada dels processos, existien algunes diferències entre el desenvolupament d'un judici inquisitorial per sodomia i la resta de casos jutjats pel Sant Ofici. Pel que fa a l'empresonament, a la resta de causes de fe era necessària la declaració de tres testimonis per empresonar l'acusat; per als sodomites n'era suficient la delació d'un únic testimoni, encara que fóra còmplice de l'acte i menor d'edat (Carrasco, 1986: 54). Ara bé, per a provar el delicte calien, almenys, tres testimonis majors de 20 anys. A Amador el van detindre pel testimoni de tres majors d'edat; molts més encara declararen en contra després, durant el judici. D'altra banda, l'autor suara citat explica que, en els casos de sodomia, l'acusat únicament rebia una monició o advertència perquè confesés el crim abans de l'acusació del fiscal, en lloc de les tres reglamentàries en la resta de causes; però Amador de Molina en va rebre, almenys, dues. Però, sense dubte, la principal diferència que presentaven els judicis pel crim nefand envers la resta era la comunicació al reu del nom dels testimonis que declaraven contra ell, concessió aquesta derivada de les clàusules de l'esmentat breu de Climent vII. Més encara, sovint encaraven l'acusat amb els testimonis durant els actes coneguts amb el nom de careos (Carrasco, 1986: 56). A tall d'exemple, el procés d'Amador recull una còpia de l'acta de la confrontació entre Amador de Molina i Gaspar Herrimén, un veí d'Asp que apareix a les confessions d'Amador amb qui va mantenir relacions sexuals al castell de dita localitat. A Herrimén, doncs, la Inquisició li va obrir el seu procés particular i es convertí, d'aquesta manera, en testimoni i acusat. Al llarg d'aquest acte de confrontació, tots dos van admetre que, efectivament, es coneixen. ${ }^{14}$ Tenint en compte aquestes diferències, certament importants, les causes de fe contra els sodomites seguien, a grans trets, els mateixos camins que qualsevol altre procés inquisitorial:

A risc de dibuixar un model de procés amb pinzell massa gros, el judici solia iniciar-se amb una denúncia a algun membre del tribunal -si no és que s'actués d'ofici-, generalment a un familiar de

14 Procés de Fe contra Amador de Molina. AHN, InQuisición, 5321, exp. 5. 
la Inquisició, més propers aquests a un delator que solia ser, en la majoria dels casos, d'extracció social mitjana o humil. Si la nòmina de testimonis inicial era suficient, l'acusat era empresonat; en el cas d'Amador, primerament a Ontinyent i, després, conduït a la presó secreta de València. Llavors s'iniciava la fase sumària, on s'havia de recollir tota la informació possible a través dels diferents testimonis. Al seu torn, l'acusat rebia les diferents monicions per tal de confessar el crim i alleugerir així la seua causa. Fins i tot en els casos d'heretgia greus, l'acusat podia retractar-se i així, si no era reincident, sovint evitava la pena de mort amb la sentència de reconciliació, amb la qual abjurava els seus errors i es reconciliava públicament amb l'Església, sempre que la seua conversió fóra manifestament sincera a ulls del Tribunal. ${ }^{15}$ Però als sodomites no se'ls prometia clemència si confessaven, sinó «breve despacho de su causa», ${ }^{16}$ perquè si l'acusat confessava plenament el delicte, era necessària l'aplicació de la pena ordinària, això és, la mort a la foguera (Carrasco, 1986: 55). Si en el transcurs de les declaracions dels testimonis i de l'acusat apareixia el nom d'altres persones com a partícips d'un delicte que estigués sota jurisdicció del Tribunal, s’iniciaven els procediments separats necessaris per jutjar-los, obrint així un procés separat que podia ser utilitzat com a prova en el cas inicial i viceversa.

Aquesta circumstància permet una retroalimentació entre diferents processos inquisitorials. En aquest sentit, Rafael Carrasco (1986) no recull el cas d'Amador de Molina entre les llistes d'encausats per sodomia que ofereix. Dels processats l'any 1588, Carrasco esmenta Francisco Bola, un morisc de Coix i Jaime Campillos Doido, també morisc i de la mateixa localitat (Carrasco, 1986: 240). El cognom apareix documentat a l'obra de la professora Ana Labarta (Labarta: 1987: 189) amb la forma Dordor, també a Garrido i Valls (2016: 132). És probable que el morisc processat que esmenta Carrasco es tracte de Jaime Dordó, ${ }^{17}$ tal com apareix al procés d'Amador, d'ofici esparter i veí de Coix. En aquesta mateixa població, Amador relata actes sodomítics amb altres moriscos, tot i que anònims, un dels quals podria ser aquell Francisco Bola de la llista de Rafael Carrasco, tot i que amb les dades que tenim no ho podem assegurar. Així doncs, a més dels dos casos jutjats el 1588 que aporta Carrasco (1986), podem afegir el d'Amador de Molina, però també aquells que apareixen a les confessions d'Amador als quals la Inquisició obrí un procés particular, com és el cas de Pedro Richarte, de Biar, i Gaspar Herrimén, d'Asp. Segurament també a Joan Baptista Alemany, el jove amb qui Amador de Molina va mantenir relacions sexuals prop d'Ontinyent, detingut igualment pels familiars de la Inquisició d'aquest poble. D'aquesta manera, la consulta creuada de diferents processos inquisitorials pot aportar-nos més dades pel que fa al nombre de processats, $i$ altres aspectes com el seu origen, residència o condició social, entre d'altres.

15 Una síntesi descriptiva del procediment inquisitorial a «La sentencia inquisitorial» (Fernández Giménez, 1999).

16 Així apareix repetidament al procés contra Amador de Molina, habitual, igualment, en altres causes de Fe i en termes similars.

17 Hem accentuat el cognom segons la pronunciació de l'ètim àrab. Agraïm l'orientació bibliogràfica del cognom Dordor a la professora Carme Barceló, de la Universitat de València. 
Després de les declaracions dels testimonis, i amonestat l'acusat, el fiscal redactava l'acusació, formada en base a les declaracions dels testimonis i del reu. Si aquest era reticent a confessar el crim, el fiscal podia demanar l'aplicació del turment per aconseguir una confessió com a prova inculpatòria. Finalment, si el tribunal donava per provada l'acusació del fiscal, s'emetia la sentència. En cas que el crim fóra plenament provat, el camí a la foguera solia ser inevitable. En aquest cas, el tribunal de la Inquisició relaxava el reu a la justícia seglar, que s'encarregava d'aplicar l'execució de la pena de mort. Aquests passos, poc dalt o baix, són els que va seguir el protagonista del procés inquisitorial que ací presentem.

\section{E1 procés per sodomia contra Amador Molina}

L'any 1588, Amador de Molina residia a Ontinyent, ciutat on va arribar, desterrat de Múrcia, i on vivia amb la seua dona i, almenys, una filla. Exercia l'ofici de porter, motiu pel qual viatjava per nombrosos llocs, sobretot, pel sud del territori valencià; sovintejava la companyia de moriscos, amb qui de manera freqüent mantenia contactes; era mestís, -«negro mulato» el descriuen els testimonis-; i practicava, de tant en tant, l'homosexualitat, «delicte» pel qual fou detingut, condemnat i sentenciat. $\mathrm{El}$ seu procés inquisitorial ens ha pervingut incomplet. Amb tot, conservem la quantitat d'informació suficient per tal d'identificar-ne la majoria de les parts. ${ }^{18} \mathrm{Al}$ llarg d'aquest article transcriurem el text fonamental per tal d'entendre com es van desenvolupar els fets: la denúncia inicial a un familiar del Sant Ofici, la detenció d'Amador a Ontinyent, les declaracions i ratificacions dels testimonis, el seu trasllat a la presó «secreta» de València, les seues confessions, les distintes monicions o advertències del Tribunal, l'acusació del fiscal i la sentència final. No el transcriurem de manera íntegra, ja que la seua extensió no permet la transcripció completa ací i ara, però aportarem les parts qualitatives de les declaracions de testimonis, bandejant les fòrmules protocol làries extenses que empraven els escrivans de la Inquisició, així com aquelles ratificacions de testimonis innecessàries, que no aporten informació rellevant.

El procés d'Amador de Molina s'inicia arran la denúncia de tres testimonis indirectes dels fets, dos cosins oriünds de Múrcia i un tercer de la localitat de Biar. El fets que desencadenaren aquesta denúncia i la posterior detenció d'Amador de Molina per les autoritats d'Ontinyent van tindre lloc durant la nit del 9 al 10 de gener de 1588. El decurs dels esdeveniments d'aquella nit ens l'aporten els testimonis que, en un o altre moment, van coincidir amb Amador de Molina en la data esmentada. Aquests testimonis, com veurem, no són els únics que s'incorporen al procés, perquè a tots aquests testimonis presencials hem d'afegir altres declaracions efectuades per persones d'Ontinyent i de pobles veïns -d'altres actes d'Amador, com a testimonis directes o d'oïdes- i, posteriorment, a d'altres testimonis que s'incorporen procedents de causes separades d'aquesta. En aquest article

18 Conservat a l'Arxiu Històric Nacional de Madrid, signatura: INQUisición, 5321, exp. 5. Disponible en línia al web del Portal de archivos españoles (pares.mcu.es). 
hem ordenat cronològicament ${ }^{19}$ les actes inquisitorials i aportem, en primer lloc, els testimonis inicials que corroboraren els fets de la nit del 9 al 10 de gener de 1588, juntament amb d'altres que declararen quelcom que havien sentit a terceres persones.

Del dia 10 de gener mateix conservem el primer testimoni del procés inquisitorial contra Amador de Molina. Aquest primer testimoni és de Joan Espí, veí de Múrcia i un dels tres denunciants inicials. Segons la seua declaració, Joan Espí era:

\begin{abstract}
labrador, vezino de la ciudad de Murçia, hierno de Pedro de Cotillas, junto a Nuestra Señora de Rexaca, en la calle del Horno de Bravo, de presente hallado en la presente villa de Ontiñente, [...] Dixo qu este testigo no conoçe al dicho Molina más de que tiene en su compañía un primo suyo, el qual se nombra Joan Espín, y le ha oydo dezir este testigo que le conoçe y le a dicho que se dize Molina y que fue tendero en Murçia y estava su habitaçión en la Puerta del Estoque; y que fue preso en Murçia por çierto insurto que havía hecho, contra un morisco, de pecado nefando de sodomía, y que por dixa razón ha sido desterrado de Murçia. Y no nada menos a oýdo dezir este testigo al mismo su primo, que en Seguín o Caravaca estuvo preso dicho Molina y que le açotaron y no sabe por qué delicto.

Y que ayer, sábado del corriente mes y año, llegó este testigo con su primo a la venta de la Vall de Biar; y este testigo, allegando cansado, se hechó a dormir. Y después de haverse adormido despertó este testigo, vió que estava cenando un hombre con un chico, el qual hombre entendía este testigo y dicho su primo que era el nombrado Molina; el qual Molina, des que hubo acabado de çenar, quiso partirse de dicha venta dixendo que havía de yr a dormir a la venta de Ontiñente. Y que este testigo, viendo [que] el muchacho que avía çenado con dicho hombre se quería yr con dicho Molina, le dixo, apiadándose de dicho muchacho, que no se fuese, que de mañana se yría con ellos; y dicho muchacho y dicho Molina quedaron a dormir en dicha venta de Biar.

Y oy domingo de mañana, antes de día dos oras, este testigo halló al dicho Molina despierto que quería partir, y este testigo dixo al dicho Molina que no se fuese, que aguardase que fuese más de día, que todos yrían; y ansí se tornaron a dormir. Y el dicho Molina estava con un çurrón en las espaldas y una bota ligada en la çinta, y que ansí se adurmieron. Y de allí a poco, este testigo sintió habrir la puerta y, despertado ya, vió que dicho Molina se yba con dicho muchacho; y bolviéndole a dezir este testigo que aguardase, que todos yrían, dicho Molina no quiso aguardar. Y quando fue de día, este testigo y dicho su primo y dos hombres, que el uno és de Biar y el otro no sabe de dónde és, se vinieron a la venta dicha de Tello, término de la dicha villa, y allí hallaron al dicho muchacho que se havía hido con el dicho Molina de la otra venta.

E interrogando este testigo a dicho muchacho, cómo le havía ydo de frío, dixo dicho muchacho que le havía traýdo aquel negro con quien havía estado en la otra venta y que le havía traýdo hasta dicha venta de Tello, donde lo dejó, dixéndole que vendría gente del Reyno de Valencia que se lo llevarían. Y bolviéndole a dezir este testigo a dicho muchacho que cómo havía pasaddo la madrugada, con tanto frío, y si dicho hombre havía llegado a la venta con él, le dixo dicho muchacho que 1 dicho hombre havía quedado en la fuente que está al pie de la montaña y enbió al chico a la venta. Y este testigo, dixéndole a dicho muchacho que por qué dicho hombre se lavava las manos en dicha fuente, y dicho muchacho, escusándose tenía vergüença, no quería dezir nada. Y este testigo [...] dixo a dicho muchacho que no tuviese
\end{abstract}

19 Indiquem a cada fragment que transcrivim la referència a la image digitalitzada del procés amb l'abreviatura Img. seguida del número de la imatge que ofereix el portal pares.mcu.es.

SCRIPTA, Revista internacional de literatura i cultura medieval i moderna, núm. 12/ desembre 2018/pp. 3470 ISSN: 2340 - 4841 doi:10.7203/SCRIPTA.12.13663 
miedo, que dijese lo que passava. Y dicho muchacho dixo entonçes que, en saliendo de la venta de la Vall de Biar, dicho Molina le apartó del camino y lo traxo a una peña y forceando con dicho muchacho, no pudiendo resistir, le cavalgó una vez. Y hallegando este testigo con la otra gente que tiene dicha y el dicho muchacho a la presente villa, luego procuró de dar voz a los familiares que examinasen dicho negosio. Y haviendo prendido a dicho Molina, dicho Molina confessó delante d'este testigo que havía dormido la noche antes en la venta de Biar y que havía traýdo dicho muchacho (Img. 25-28).

Així doncs, aquest primer testimoni va declarar que no coneixia personalment Amador, però el seu cosí sí, i aquest li va fer saber que Amador ja havia sigut desterrat de Múrcia per mantenir relacions sexuals amb un morisc, entre d'altres delictes que no podia determinar. Testimoni d'oïdes a banda, la declaració de Joan Espí ens serveix per emmarcar el començament d'aquest procés, uns fets inicials que convindrem de resumir més avall, quan finalitzen les declaracions de tots els testimonis inicials i abans del trasllat d'Amador a la presó «secreta» de València.

La següent declaració conservada per ordre cronològic va tindre lloc el mateix dia i correspón a Joan Espí, homònim i cosí de l'anterior, un altre dels denunciants inicials, qui -recordem- sí que havia conegut Amador durant la seua estada a Múrcia:

El qual dixo que este testigo, con Joan Espín, su primo, de la misma çiudad de Murçia, allegando anoche sábado en la venta de la Vall de Biar, ya tarde y de noche, que serían ocho oras, allegó a dicha venta un hombre que este testigo conoçía muy bién, que se dize Molina, [...] el qual Molina traýa en su compañía un muchacho mal vestido. Y dicho Molina y el muchacho çenaron los dos y, en haver çenado, dicho Molina se quería ir con dicho muchacho; y este testigo y su primo le dixeron que no se fuese, que de mañana se yrían todos. Y ansí se quietó dicho hombre, el qual, antes que se hiziese de día dos horas poco más o menos, se fue con dicho muchacho. Y siendo de día, este testigo y dicho su primo y dos otros, uno de Biar y el otro de Valençia, que no los conoçe, se vinieron hasta la venta dicha de Tello, término de la presente villa, adonde allaron el muchacho que partió en la madrugada de la otra venta de Biar. E interrogándole a dicho muchacho de cómo havía quedado allí sin el hombre, dicho muchacho respondió que se havía huýdo el dicho hombre. Y bolviéndole a pedir que por qué, dicho muchacho dixo que no, por nada. Y bolviéndole este testigo a preguntarle al muchacho, tuviendo notiçia de la mala fama del hombre, haviendo induzido a dicho muchacho que dixese lo que pasava, dicho muchacho respondió que le havía apartado del camino en la muntaña y que le havía forçado quitándole los çaragüelles y le avía puesto sus vergüenças en la mano del dicho muchacho, y no pudiendo resistir le cavalgó una vez. Y después, partiendo este testigo y los demás con dicho muchacho de dicha venta hazia la presente villa, el dicho muchacho les dixo que dicho Molina le dezía que si se lo quería hazer, y le tomava sus vergüenças y se las ponía detrás. Y llorando dicho muchacho, se huýa, y dicho Molina le dixo que no tuviese miedo, sino que se fuese a la venta, que unos hombres que yban hazia baxo lo traerían a Valençia. Y en allegando este testigo con los demás dieron quexa a los familiares de la Inquisición. Y después ha visto este testigo cómo traýan preso al dicho Molina y al muchacho (Img. 29-31).

D’aquell mes de gener no es conserven més testimonis. La següent declaració, la de Gaspar Joan Sancho, es va produir l'1 de febrer de 1588, davant mossèn Jeroni Llinares, comisari del Sant Ofici d'Ontinyent. Aquest Gaspar Joan, junt amb Jaume Romeu, tots dos familiars del Sant Ofici, van ser els encarregats de detindre l'acusat: 
E dixo que un domingo pasado, que ha tres semanas poco más o menos, fue hecha requesta a este testigo y al magistrado Jayme Romeu, como familiares del Santo Oficio de la Inquisición, por un hombre de Biar y otros forasteros de Murçia, que estavan en el mesón de Nofre Navarro, que tomasen preso a un negro o mulato que se dize Molina, que está en la presente villa, porqué se dezía que havía cavalgado un muchacho que estava allí con ellos. Y así este testigo, viniéndole al encuentro el dicho Molina negro junto al mesón de Nofre Navarro, antes de llegar a él, así a los murçianos como al muchacho que allí estava, [preguntó] si era aquel el negro, y diziéronle que sí. Y ansí le tomó este testigo, diziéndole: «tenéos preso por el Santo Officio». Y dixo el dicho Molina que por qué lo prendía, y este testigo le dixo: «en parte yréis, que bién lo sabréis». Y ansí este testigo y Nofre Navarro y su hijo y otros que allí estavan, a los quales requirió que le acompañassen, lo traxeron a la cárçel y juntamente traxeron al muchacho y les pusieron en prisiones distintas, y dieron razón al justicia, requiriéndole los tuviese a buen recaudo.

Y és acordante este testigo que después que está preso el dicho negro, le dixo Bartholomé Hernández, portero que reside en la presente villa, que en días pasados, viniendo el dicho Hernández de Biar a la presente villa en companyía de Joan Lescano, de un castellano y [un] aragonés, el dicho castellano y aragonés les contaron por el camino que el dicho Molina, negro, que havía estado aquella noche en Biar en un mesón, estando en la cozina, el dicho negro les ponía las manos en los çaragüeles queriéndoles tocar sus vergüenças; y que estuvo el uno d'ellos por darle de puñaladas, si se allara puñal, y que el dicho Bartholomé Hernández dixo a Joan Lescano, que venía detrás: «mira qué dizen aquí de vuestro suegro». Y los dichos forasteros se lo contaron otra vez (Img. 10-11).

Gaspar Joan Sancho, doncs, a banda de relatar la captura d'Amador -que és el que li requerien-, va explicar uns actes «deshonestos» que havia fet Amador de Molina aquella citada nit de gener amb un aragonés i un castellà. Aquests van contar els fets a Joan Lescano i Bertomeu Hernández, i aquest darrer a Gaspar Joan Sancho, el qual aprofitava l'avinentesa per donar testimoni d'oïdes.

Un altre dels testimonis inicials dels fets és Joan Mollà, oller d'ofici, habitant de Biar i el tercer dels denunciants que van donar part als familiars de la Inquisició d'Ontinyent. Malauradament, d'aquest no conservem la seua declaració inicial, la qual va tindre lloc el dia 10 de gener, però sí dues ratificacions del seu testimoni: la primera, efectuada l'1 de febrer; i la segona, el 21 de març de 1588 «llamado a [la] presente villa [d'Ontinyent] con carta dirigida al justicia de la villa de Biar, a instancia de los magistrados Jayme Romeu y Hierónimo Colomer» (Img. 14). Durant la seua primera ratificació li van llegir la seua declaració inicial «de la primera línea hasta la postrera, diziéndole el dicho señor comissario que estuviese atento y que mirase si havía alguna cosa que añadir o quitar» (Img. 14). L'oller de Biar, oïda la seua anterior declaració, decidí afegir el següent:

Que quando los familiares de la villa de Ontiñent, que eran Gaspar Joan Sancho y otros que no les sabe el nombre, tomaron preso al dicho Molina, negro o mulato, por la requesta que este testigo y los murçianos les hizieron, que fue junto al mesón de Nofre Navarro, antes de tomarlo dixeron al muchacho que estava en presençia de los murçianos y de este testigo que si era aquel el negro que le havia cavalgado y el dicho muchacho dixo que sí, que aquel era; y los murçianos dixeron también que aquel era el negro que havia llegado la noche antes a la venta de Biar con aquel muchacho que está allí con ellos y se havía partido en la madrugada con el dicho muchacho de la misma venta (Img. 14-15). 
El 21 de febrer, al llarg de la seua segona ratificació, explica:

que conose al dicho Molina de vista, de haverlo visto en Biar, que traýa algunas execusiones. Y también lo vió en la presente villa quando lo prendieron los familiares del Santo Officio a instancia d'este testigo y de unos hombres de Mursia (Img. 16).

Abans de la segona ratificació de Joan Mollà, i retornant a l'ordre dels fets, el 5 de febrer de 1588 va declarar Bertomeu Hernández, d'ofici porter i vei d'Ontinyent, el qual:

fue interrogado que diga lo que en días pasados le contaron dos hombres forasteros, viniendo de Biar a la presente villa, que les havía aconteçido con Molina, negro o mulato, que reside en la presente villa.

E dixo que a mes y medio, poco más o menos, qu este testigo estuvo en Biar, en el mesón de Caçorla, y juntamente estava en el dicho mesón el dicho Molina, negro, y Joan Lescano, todos porteros, y otra gente forastera. Y durmieron aquella noche en dicho mesón y por la mañana se partieron este testigo y Joan Lescano y dos forasteros, el uno dixo que era de Chinchilla y el otro de Aragón, para venir a Ontiñent. Y por el camino le dixo el dicho hombre de Chinchilla a este testigo que, si la noche pasada, estando en la cozina, se hallara un puñal, diera de puñaladas al negro que estava allí con ellos en la cozina. Y diziéndole este testigo por qué, dixo que estando asentado en el banco de la cozina a su lado el dicho negro, diziéndolo por el dicho Molina, le ponía la mano en los çarahueles queriéndole tocar sus vergüenças y que por esso se lebantó de allí y se fue a costar, por no reñir con él. Y de allí a poco vino el aragonés a dormir a la misma cámara y, diziéndole el dicho aragonés al castellano que por qué se havía acostado tan temprano, le dixo la causa, y el aragonés respondió: «Lo mesmo me a conteçido después que os fuystes de allí». Y entonçes este testigo llamó a Joan Lescano, que venía un poco detrás, diziendole: «Venid a ver lo que qüentan estos hombres de bien de vuestro suegro», diziéndole por el dicho Molina, negro, el qual dicho Lescano festea su hija. Y ansí se lo bolvieron a contar los dichos forasteros al dicho Joan Lescano. Y por el camino venian chacoteando con los forasteros del negoçio del negro (Img. 17-18).

El 8 de febrer de 1588, el comissari de la Inquisició d'Ontinyent, Jeroni Llinares, interrogava el cirurgià Nofre Llança, veí d'Ontinyent, a fi que explicara el que havia sentit sobre Amador durant un viatge a Caravaca. El testimoni va declarar -d'oïdes, doncs- el següent:

A veinte días poco más o menos, que estando este testigo en Caravaca, juntamente con Melchior Torró, vezino d'esta villa, en un mesón junto a la yglesia, hoyeron dezir al mesonero que aquellos días havían quemado allí en Caravaca un cativo porque lo havían allado con una somera. Dixo entonces el dicho Melchior Torró que en Ontinent estava preso un mulato porqué, se dezía, havía cavalgado. Y dixo el mesonero [si] por ventura sería Molina, y dixéronle que sí. Y el dicho mesonero les contó que el dicho Molina, negro o mulato, havía estado preso allí en Caravaca por lo mesmo y no se le provó, y también fue preso en Mula y traído a Murçia por la misma razón y no se le provó lo que le inculpavan (Img. 21).

El següent testimoni conservat és el de Joan Lescano, també porter d'ofici, el qual sí que va estar present el dia dels fets i, tal com es desprén del procés, havia tingut algun tipus de relació amb la filla de l'acusat. Així doncs, el 13 de febrer de 1588, Joan Lescano:

dixo que quinze días poco más o menos antes de Navidad, estuvo este testigo en Biar, en el mesón de Caçorla y juntamente estava Bartholomé Hernández y el dicho Molina. Y este testigo durmió algunas noches con el dicho Molina, qu estavan presentados en dicha villa por ciertas execuçiones. Y quando este testigo se bolvía a la presente villa, juntamente con 
Bartholomé Hernández y dos forasteros que havían dormido el día antes en dicho mesón, que el uno d'ellos era aragonés y el otro castellano, de Chinchilla, al qual este testigo después ha visto algunos días en casa de Antonio Albuxech, que trabajava de perayre. Y reçagándose un poco en el camino este testigo, el dicho Bartholomé Hernández lo llamó diziendo «Agüija, mira que dizen aquí de vuestro suegro, que se ha vuelto ordeñador», diziéndolo por el dicho Molina, negro mulato, que de presente está preso en la cárçel de la presente villa. Y el dicho castellano y aragonés le contaron que la noche en antes el dicho Molina, estando en la cozina en medio de los dos, les palpava las braguetas y al uno alcançó a tocarle las vergüenzas, el qual dixo que si tuviera un puñal le uviera dado de puñaladas, y vinieron riendo y burlando d'ello por el camino.

Fue interrogado si las noches que durmió en Biar, con el dicho Molina, si le hizo el dicho Molina algún semejante acontecimiento. E dixo que tal cosa no hizo ni acometió, empero, a oýdo dezir este testigo a Antonio Torres, hijo de maestre Antonio Torres, cadirero de la presente villa, que durmiendo el dicho Antonio Torres en Albayda, en la cozina del mesón de Colomer, el dicho Molina le palpava sus vergüenzas. Y diziéndole el dicho Torres al dicho Molina que se fuese en hora mala, le dixo el dicho Molina: «Calla, que has de ser mi hierno». Y también oyó dezir este testigo a Pere Llodia que se lo havía contado el dicho Torres. Y quando prendieron estos días pasados en la presente villa al dicho Molina, negro, dixo el dicho Llodia a este testigo: «Mira lo que yo te conté de Molina, ya dizen que lo an tomado» (Img. 33-35).

El testimoni de Joan Lescano explica dalt o baix el que ja havia declarat Bertomeu Hernández, però afegeix el que li havia explicat Antoni Torres, fill i aprenent de cadirer, sobre suposats actes deshonestos que hauria tingut Amador de Molina amb ell, a l'hostal de Colomer, a la localitat d'Albaida. Tant Joan Lescano com Antoni Torres, com veurem, apareixen també a la primera declaració d'Amador. Com a resultat, segurament, d'aquesta declaració de Molina, la Inquisició va cridar a declarar l'esmentat Antoni Torres, que va comparéixer a Ontinyent el mateix dia 13 de febrer de 1588:

Antonio Torres, cadirero, menor de días, vezino de la villa de Ontinyent, hijo de maestre Antonio Torres, de edad según dixo de dezisiete o deziocho años, testigo que juró dezir verdad. Fue interrogado por el dicho señor comissario que diga lo que le aconteçió en Albayda con Molina, negro mulato, que de presente está preso en la presente villa. E dixo que a quatro meses, poco más o menos, que estando este testigo juntamente con su padre trabajando de su officio en la villa de Albayda, una noche dormía este testigo en un banco de la cozina del mesón de Colomer y estava asentado junto a él el dicho Molina, negro. Y sintió este testigo que el dicho Molina le ponía la mano ençima las cuxas, que sería a la oración de las almas. Y este testigo, pensando si le buscava la bojaca de los çaragüeles o bolsa, se quitó de allí y se mudó en el otro banco. Y estando durmiendo se despertó y sintió que le tocavan sus vergüenças. Y el dicho Molina se las tenía en la mano y no quería dexar la presa, y este testigo le apartó la mano diziéndole: «iquitaos de aý, en hora mala! Tenéis muger como un horo y vais a palpar los hombres». Y el dicho negro le respondió que su muger no quería negoçiar con él, y este testigo le respondió que se fuese al burdel y quitóse de allí el negro, y se fue de la cozina.

Y después, otro día, estava este testigo, ya de noche, asentado en un banco en la plaça de la presente villa con una guitarra en la mano, se le asentó al lado el dicho Molina, negro, y también le ponía la mano en los çaragüeles, y este testigo le hizo quitar de allí. Y otro día le dixo el dicho Molina a este testigo que fuese a su casa y le adobaría un banco; y este testigo, por lo que dicho tiene, no quiso yr y ansí se lo embió a casa a dobar. Y otro día, yendo este testigo a la huerta, encontró junto al monasterio de las monjas al dicho Molina, el qual dixo a 


\begin{abstract}
este testigo que adónde yba, y este testigo le respondió que a la huerta. Y el dicho Molina le dixo: «¿Queréis que vaya con vós?» Y este testigo le respondió que se fuese en ora mala, que no lo havía menester. Y quando fue un poco más adelante vió este testigo que el dicho Molina le venía detrás y este testigo le dixo que adónde yba, y respondió el negro: «a ayudaros». Y este testigo le dixo: «No quiero que vengáys, sino que os bays en hora mala, antes que os rompa los morros». Y ansí se fue y no le a dicho más cosa alguna hasta fiestas de Navidad más çerca pasadas, que dixo a este testigo que viniese a su casa y le combidaría a orelletas, y este testigo le respondió que se fuese en ora mala, que no lo quería ver a él ni sus orelletas. Y después no le a dicho otra cosa.

Y estando este testigo en compañía de Pere Lodía, moço hijo de Bartholomé Lodía, y otros que no se acuerda, pasó por allí el dicho Molina, negro, y empeçaron a hablar los que estavan con este testigo de la muger y hija del dicho Molina, y este testigo les contó lo que le havía suçedido con él en Albayda. Y el dicho Lodía le dixo: «Si buelve otra vez a querer hazer lo semejante, imbíalo en hora mala que e oýdo dezir que a estado preso en Murçia, increpado de cosas de bujarrón». Y también contó este testigo otro día a Joan Lescano lo que le havía suçedido en Albayda con el dicho Molina. Y esto y no más dixo saber este testigo açerca de lo susodicho (Img. 37-39).
\end{abstract}

Poc o gens tenia a veure el testimoni de l'aprenent de cadirer amb els fets que van motivar la denúncia, però les declaracions de Joan Lescano i Amador de Molina sobre altres fets, a priori aliens al procés, van propiciar que Antoni Torres fóra cridat a declarar, aportant així més proves sobre la conducta d'Amador.

Pel que fa al testimoni del jove que suposadament va ser víctima dels abusos d'Amador aquella nit, aquest ens ha arribat fragmentat i només conservem el final de la seua primera declaració -sense data, doncs- i la seua ratificació, que va tindre lloc el 10 de març i en la qual va reafirmar allò declarat, sense afegir res més. Gràcies a l'acusació del fiscal, que reproduïm més avall, coneixem el seu nom, Joan Baptista Alemany, i que era veí de València, però res més se sap d'ell. Abans del 10 de març, doncs, va comparéixer per declarar el següent:

[...] los dos juntos de la dicha venta y quando fueron çerca de la montaña dixo el dicho negro a este confesante semejantes palabras: «qquieres que hodamos?» $\mathrm{Y}$ este confesante le dixo que no. Y queriéndole tomar el negro, se huyó este confesante y el dicho negro lo alcançó y le tomó de la mano y lo apartó del camino y en unas peñas cavalgó a este testigo y confesante una vez, metiéndole su miembro por el culo d'este confesante y, gritando este por no consentir, el dicho negro le tapava la boca.

Fue interrogado si después de averle cavalgado el dicho negro, si fueron los dos juntos. E dixo que sí, que los dos juntos se fueron hasta otra venta qu está más çerca de Ontiniente y en una fuente que está antes de llegar a la venta se lavó las manos el negro. Y allegaron a la dicha venta quando se hazía de día y almorçaron sardinas. Y después de almorçado se fue el negro, diziéndole a este confesante que se quedase allí y se podría venir con aquellos hombres [que] venían detrás, y así se quedó este confesante. Y dicho negro le dixo que no dixese nada de lo que avía pasado, sino que callase. Fue interrogado si el dicho negro ponía sus vergüenzas en la mano de este confesante e dixo que sí y qu este confesante no se las quería tocar y el negro le tomó las manos y se las hizo tocar. Fue interrogado si el dicho negro tocava e palpava las vergüenzas de el dicho confesante y le dezía: "hódeme tu a mi". Y dixo que no, ni tal cosa le dixo el negro. Fue interrogado si antes de llegar a la venta de Biar, o después, el dicho negro cavalgó otra vez al dicho confesante. Dixo que no, ni a pasado con él otra cosa más de lo que tiene dicho. (Img. 55-56) 
Fins aquí hem recollit totes les declaracions conservades que els diferents testimonis efectuaren contra Amador a Ontinyent. També conservem part de la primera declaració d'Amador, encara a la comarca de la Vall d'Albaida, efectuada poc després de la seua detenció a mans de Gaspar Joan Sancho i Jaume Romeu, familiars del Sant Ofici. Abans, però, de continuar amb el procés, considerem oportú de resumir i ordenar els fets que motivaren l'arrest d'Amador de Molina:

Al voltant de 15 dies abans de la festivitat de Nadal de 1587, Amador de Molina es trobava a la vila de Biar juntament amb Joan Lescano, que segons sembla mantenia relacions amb la filla d'Amador, i Bertomeu Hernández, tots tres d'ofici porters. Exercint la seua professió, portaven «execusiones» a Biar, segons afirma Joan Mollà, oller de Biar i que, segurament, havia coincidit amb tots tres $-\mathrm{O}$ almenys amb Amador, segons explica a la seua ratificació- abans de la nit dels fets. Allí, a l'hostal de la Vall de Biar, segons uns, o de Caçorla, segons altres, van pernoctar bastants nits, durant les quals, segons Lescano, no va ocórrer res d'especial.

El fets deurien transcórrer amb relativa normalitat, atés que cap dels declarants menciona cap incident destacable. Fins la nit del 9 de gener de 1588, quan Amador va arribar a l'hostal amb Joan Baptista Alemany, un jove de València. Al mateix hostal arribaren poc després els dos cosins de Múrcia, tots dos de nom Joan Espí, els quals, fatigats pel viatge, decidiren d'anar a dormir. Amador, el jove Joan Baptista Alemany, Joan Lescano i Bertomeu Hernández s'aplegaren al voltant de la taula de la cuina de l'hostal per sopar. A l'àpat s'uniren dos anònims personatges, un aragonés i un castellà de Chinchilla. En algun moment del sopar, segons les declaracions, Amador li va tocar els genitals al castellà, que es va retirar a dormir pensant que, si haguera disposat d'un punyal, l'hagués cosit a punyalades. L'aragonés es va gitar poc després. Per la seua banda, els dos cosins de Múrcia -no sabem si es van desvetllar o, una vegada havien descansat del viatge, van decidir sopar amb la resta- van aconsellar Amador que aguardés que fóra de dia abans de marxar. Però sembla que Amador tenia pressa per anar-se'n a Ontinyent -de nit i en ple hivern- amb el jove Joan Baptista.

Tot i això, abans de l'alba, un dels cosins Espí va interrompre el primer intent de partida d'Amador. La segona vegada no ho va poder impedir i Amador i Joan Baptista Alemany se n'anaren de l'hostal. En un punt indeterminat del trajecte que unia Biar amb Ontinyent, segons els testimonis, Amador de Molina va apartar del camí el jove i, darrere d'una penya el va forçar, tot penetrant-lo analment. Per la seua banda, els dos murcians i l'oller Joan Mollà, una vegada va amanèixer, van iniciar camí cap a Ontinyent. En arribar aquests darrers prop l'hostal de Tello, a Ontinyent, van trobar el jove Alemany, que, després d'un insistent interrogatori, els va confessar que Amador havia abusat sexualment d'ell. Els dos cosins i Joan Mollà van denunciar els fets a Gaspar Joan Sancho i Jaume Romeu, familiars del Sant Ofici. Finalment, aquests darrers van detindre Amador i Joan Baptista a la presó d'Ontinyent.

Malauradament, de la primera declaració d'Amador només conservem un fragment sense data que, tanmateix, ens aporta informació que ens permet reconstruir part d'aquesta primera sessió interrogatòria. Cal tenir present que, malgrat les declaracions aportades per alguns testimonis 
segons les quals Amador hauria mantingut $-\mathrm{O}$ intentat mantindre- relacions homosexuals amb diferents homes, el desencadenant de la seua detenció va ser la denúncia amb motiu de la suposada violació del menor -i, sobretot, home- Joan Baptista Alemany. Aquesta denúncia suposava per a la Inquisició un motiu suficient per tal d'incoar el procés inquisitiu i iniciar així la recollida de testimonis. A partir d'aquell moment, doncs, l'objectiu del tribunal en aquesta fase sumària era la recopilació de proves suficients que aportaren llum al procés i poder determinar així la veritat de l'assumpte en qüestió.

La manera més ràpida d'acabar amb un procés inquisitorial era la confessió jurada del crim pel qual havia estat detingut l'acusat. A les causes del Sant Ofici contra l'heretgia, en aquesta fase sumària, no es comunicava els motius de la detenció i s'esperava que l'acusat, fent un acte de contrició, netegés la seua consciència i confessés els crims. Hem vist com, per contra, per als casos de sodomia, el nom dels testimonis es feien públics a l'acusat. Encara que aquest fet no s'hagués produit, hom pot pensar que, si és cert que hagués mantingut relacions sexuals amb Joan Baptista poc abans de la seua detenció, Amador hauria d'ésser conscient -O almenys tenir una idea- de quins eren els motius de la seua captura. D'altra banda -i amb les reserves de continuar trepitjant el camí de les suposicions- creiem més probable que, en algun moment, el Tribunal relatés a Amador el testimoni de Joan Baptista, per bé que aquest extrem no el podem confirmar amb la documentació del procés; com també és possible que s'hagués produit una confrontació de Joan Baptista amb Amador a la sala del Tribunal, com la que va tenir lloc més endavant, com veurem, amb el testimoni Gaspar Herrimén. Allò cert és que en aquella primera declaració d'Amador no hi ha cap referència als fets detonants del seu empresonament; en canvi, no sabem si per alliberar la seua consciència o per contentar els interrogadors, Amador va declarar:

[...] siendo su criado, un hijo suyo de hasta veynte años, llamado Viçente, andava mostrando a este sus vergüenças y cada noche que dormían los dos en el pajar, este le tocava sus vergüenças e le hazía la puñeta algunas vezes, quatro o seis vezes en diferentes días, e luego dixo que serían diez vezes, porqué estubo un mes con él, e con este no pasó más.

Ítem dixo que con un sobrino del dicho Castelló, llamado Julián, labrador, mancebo, a las mañanas que durmían juntos en el pajar, el dicho Julián se ponía enzima de sus vergüenzas el cubrepan, qu es como una pala que, dezía él, le sustentava en el miembro alçado. Y este le tomava con la mano sus bergüenças. Solamente una vez le hizo la puñeta.

Ítem dixo que con otro moço llamado Pedro Esparça, que dezía era de Vallada, que trabajava con el dicho Castelló, le tomó este sus vergüenças e le hizo la puñeta una vez nomás, que bive en Ontiniente en casa de Jaime Usina, labrador, que no sabe cuyo hijo es, que abrá esto y lo de Castellón un año que pasó.

Ítem dixo, que con otro que se llama Juan Lescano, natural de Ontiniente, correo que lleva letras, este le tomó sus vergüenças estando durmiendo juntos en una cama de un mesón de la villa de Biar y no pasó otra cosa más de tocárselas. E qu esto abrá un més e que no se acuerda si este le hizo la puñeta o se la hizo él.

Ítem dixo que con otro moço que tiene una barraca cerca de la heredad de Castelló, en Ontiniente, que no le sabe el nombre, yendo este a coxer unas espinacas que heran del moço, este le tomó su miembro con la mano e le hizo la puñeta e no pasó otra cosa con él. Que el Castelló sabe cómo se llama este moço y abrá u año que fue. 


\begin{abstract}
Ítem dixo que abrá mes y medio que estando este en Albayda una noche durmiendo en la cozina del mesón, un moço llamado Antón se llegó a este y este le puso la mano sobre la rodilla, y luego el Antón se hechó enzima del banco donde este estava sentado y se acercó a este y le metió este la mano por los çaragüelles y le tocó sus vergüenças una vez o dos, y le hizo con la mano la puñeta. Y después, otra vez en Ontiniente, estando los dos sentados debaxo de un porche, este le metió la mano a sus vergüenças y se las tocó y le hizo la puñeta dos vezes. E que este moço se llama Antón y es cadirero e bive en Ontiniente e que no se acuerda agora de otra cosa.

Preguntado si quando dize que el dicho Richarte cavalgó a este, si fue con su boluntad y lo consintió este, porqué no es cosa verosímil que el dicho Richarte le hiziese fuerça, como tiene dicho, siendo como es hombre de fuerças, dixo que, como dicho tiene, contra su boluntad e por fuerça cavalgó a este el dicho Richarte, estando este medio dormido e que no tiene más que dezir, so cargo del dicho juramento (Img. 75-77).
\end{abstract}

D'entre els actes exposats en aquesta declaració destaquen en primer lloc els que tingueren com a protagonistes Joan Lescano, que festejava la filla d'Amador, i Antoni Torres, l'aprenent de cadirer, les versions dels quals divergeixen sensiblement del que va declarar Amador. Potser aquesta declaració d'Amador provocà la compareixença d'Antoni Torres; també, en part, la de Joan Lescano, malgrat que aquest va ser cridat a declarar per aclarir què va passar la nit del 9 al 10 de gener. Un altre implicat destacat en aquest procés és Richarte, de nom Pere, com comprovarem més avançat el procés, el qual serà igualment detingut i processat. En qualsevol cas, la Inquisició no va obtenir en aquella sessió la declaració jurada que esperava en allò referent a la violació de Joan Baptista, motiu que propicià la seua primera monició o advertència:

\footnotetext{
Fuele dicho que en este Santo Officio no se prende a ninguno sin bastante información de aver hecho o dicho, visto hazer o dezir a otra persona cosas que son o parezen ser en ofensa de Dios nuestro señor, cuyo conoscimiento pertenece a este Santo Officio. E pues él a sido traýdo preso, deve enteneder, a sido con esta información [...] Por tanto se le amonesta por primera monición de parte de Dios nuestro señor e de su gloriosa madre, la Virgen sancta María, que diga e confiese la verdad, si tiene más que dezir de lo dicho e confesado, porqué haziéndolo así salvará su ánima y su causa tendrá más breve despacho, sin encubrir cosa alguna de sus delictos e sin levantar a nadie falso testimonio (Img. 77-78).
}

Però Amador va comunicar al tribunal que no tenía res més a dir i, per tant, la seua causa s'hauria d'allargar. Fins aquest punt, tot el procés ha esdevingut a la localitat valldalbaidina d'Ontinyent. Però una vegada recopilats els testimonis suficients, el procés havia de continuar a la ciutat de València, excepte les ratificacions de testimonis d'Ontinyent, que declararen a la seua ciutat. L'ordre de trasllat s'emet el 12 de febrer de 1588 (Img. 3). Set dies després, el 19 de febrer de 1588, Amador de Molina arriba a València i és entregat a Andrés de Castro,

alcayde de las cárceles de este Santo Oficio, confessó haver recibido de Miguel Joan, ayudante de aguazil d'este Santo Officio, la persona de Molina, mulata, para ponerle en las cárceles secretas d'este Santo Officio. Fue reconocido y no se le allaron cosas prohibidas y lo firmó de su nombre (Img. 4).

La primera declaració conservada d'Amador a València es va produir el 24 de febrer de 1588. En aquella ocasió, de nou, lluny d'explicar la relació mantinguda amb el jove Joan Baptista, camí de Biar a Ontinyent, va declarar: 
Que en Biar, a un criado de Gómez, cartero, que lleba letras, de cuyo nombre no se acuerda, estando durmiendo juntos en una cama del mesón, este le tomó sus bergüenzas en la mano y no pasó más de este tocamiento.

Ítem dixo que también en la villa de Ontiniente a Miguel Muñiz, hijo de Muñiz, durmiendo juntos en una hera este berano pasado, por la siega, que no se acuerda particularmente qué día era, este le tomo su miembro en la mano e le començó [a] hazer la puñeta y el dicho Muñiz se le quitó e la hizo él.

Ítem dixo que en la dicha villa de Ontinyente, abrá siete o ocho meses, en yendo este [a] una cueva alquilarda de las qu estan enzima del río, yvan allí algunos hombres a jugar. E un moço natural de la Ollería, llamado Luís, qu es abaxador, que a estado con Soler, arrendador de los diezmos de Ontinyente, y al presente está en la Ollería e que no sabe otras señas más de que le llaman el Borde, algunas bezes, de día, se benía a hechar dónde este estava y, bestidos entre día, este le tomava de su miembro genital e le hazía la puñeta y el dicho Luís a este; el qual también quería cavalgar a este por detrás y este no lo consintió. Y así se puso enzima de este por delante y entre las piernas d'este, apretándose con él, hechó simiente, lo qual pasó dos vezes en diferentes días. E que con este no pasó otra cosa, lo qual dixo llorando, e que havía remedio para él, que no a conoscido a Dios hasta agora.

Ítem dixo que con otro moço llamado Pedro, sobrino de la garvançera, mancebo por casar, que no le sabe otras señas ni cuyo hijo es, qu es trabajador, este le tomo su miembro en la mano por dos vezes en diferentes días e le hizo la puñeta abrá como ocho meses, que no se acuerda del día, y no hizo otra cosa con él.

Ítem dixo que con un morisco qu es de Villalonga, que haze bedriado, qu es un moço alto de cuerpo, cuyo nombre no sabe ni quién són sus padres, que venía a bender bedriado a Ontinyente y a Xàtiva y a otras partes y no sabe más señas d'él, que quando habla tiene por costumbre de cerrar el un ojo; beniendo este de Gandía se topó con una carga de bedriado que la llevaba a Xàtiva, cabe la Puebla, el qual dicho morisco quiso cavalgar a este por detrás. E no queriendo este consentir, dixo el dicho morisco que de presto lo haría por la boca, y este tanpoco lo consintió. Y el dicho morisco, estando los dos en por detrás de una çarça, se lo hizo por detrás entre las piernas, sin meterle su miembro por el culo d'este, quitados los çaragüelles de uno y el otro, e diziéndole este que cómo havía de hazer por la boca. El dicho morisco dixo que con otros lo avía fecho e que no supo contestar más, e que esto pasó en el campo junto a la Puebla del Duque.

Ítem dixo que en el lugar de Montichelvo, en este reyno, abrá como un año, este se topó con un morisco cuyo nombre no se acuerda, más de que hera un morisco pequeño, las piernas gordas, moço como de veinte a beynte e dos años, que le apuntava la barba, no muy moreno ni muy blanco sinó trigueño; junto a la fuente cerca del lugar, el qual morisco traýa a cuestas aces de leña para el mesón de allí, e que hera natural de Castellón del Duque, dónde tenía una hermana o cuñado. El qual se allegó a este y, después de aver raçonado, le vino a dezir que se fuesen allí abaxo a una calera, e que si este levava algunos dineros que dalle. Y ansí fueron allá, el qual dicho morisco quiso cavalgar a este por el culo, estando este desatacado y los dos en pie, por ser junto al camino. Y el dicho morisco apretó con este e se juntó con él por detrás y entre las piernas d'este, sin meter el miembro, hechó simiente entre las piernas. E pidió a este que si tenía algún dinero que le dar, porqu él avía benido con un fraile des de Murçia y le dio quinze reales porque durmiese con él dos noches e hiziese lo que él quisiese. E, preguntándole este qué fraile era, le dixo que hera de los hábitos negros y blancos, de Valençia o de Murçia, de veynte años hasta treinta años, e que no pasó otra cosa con él ni después jamás le a visto ni sabe quién es, que la mesonera dirá quien es.

Ítem dixo que con otro morisco de Castellón del Duque, qu es arriero y tiene dos mulos, moço pequeño de cuerpo, de hasta veinte años, blanco, cuyo nombre no sabe ni cuyo hijo 
es, estando una noche en la villa de Alcoy, abrá como tres meses, en el mesón de Monçón, estando hechado en una xalma suya y el otro en otra junto este, le puso a la media noche la mano enzima de sus bergüenzas, qu estava desnudo el dicho morisco; se puso enzima d'este por detrás, dos o tres vezes, procurando meter el miembro en el culo d'este y, no pudiendo, hechó simiente entre las piernas d'este y no pudo más con este.

Ítem dixo que al hijo del dicho mesonero, llamado Agustín, este le tomó su miembro con la mano e le hizo la puñeta por el mismo tiempo e que no pasó con él otra cosa.

Ítem dixo, que en el mismo mesón de Monçón, durmiendo este en el pajar, un moço llamado Alonso, natural de Quesada, qu es çurdo e manco de un dedo, se dava con su miembro en la barriga y este le tomo con su mano e le hizo la puñeta dos vezes en diferentes días en el mismo mesón. Y otra vez [...] en la villa de Ontiniente fue a la posada d'este y allí le hizo este la puñeta e no pasó otra cosa, qu es moço alto, moreno, los dientes juntos e que no sabe más señas. Ítem dixo que con otro moço llamado Andrés, que dixo hera de Biar, pastor, que es dentudo, qu es pastor de uno de Ontiniente que tiene unas cabras, que no sabe cómo se llama su amo; el qual abrá un año que, durmiendo en casa d'este en Ontiniente, vestido, y este con él, aunque el uno y el otro desatacados, el qual Andrés se subió enzima d'este por detrás y hechó simiente entre las piernas, sin meter su miembro en el culo d'este, aunque pensava el dicho Andrés que lo tenia dentro, porqué este apretó las piernas, y qu esto fue dos vezes. Y este también se puso enzima del dicho Andrés, por detrás, e no pudo cavalgarle porqué se le doblava el miembro. Ítem dixo que con otro moço moreno, redondo, de Bañeras, llamado Rafael, estando entrecavando en una heredad de Nofre, estava en la torre de una casa que tiene allí, durmiendo los dos en un pajar, este le puso la mano en su miembro. Y luego el dicho Rafael se puso enzima d'este por detrás, estando este desatacado y el Rafael también. E, por tener el miembro tan grande, este no consintió que le cavalgase. E se quitó luego y este se le puso enzima por detrás al dicho Rafael e no pudo cavalgarle porque se le doblava, ni hechó este simiente. Y el dicho Rafael, haziendo la puñeta con su mano, hechó simiente.

Ítem dixo que estando en Biar por el tiempo de las uvas, abrá un año, estando en la viña de Pero López, dueño de la venta de Biar y de la viña, este le hizo la puñeta, tomándole su miembro con la mano con las vardas de las viñas; y el dicho Pero López tomó a este su miembro y le hizo la puñeta una vez nomás.

Ítem dixo que, biniéndose de Ontiniente a Biar, alló labrando al dicho Pero López. Y este tomó los bueyes y labró un rato con ellos, y le dixo a este que biniese alguna vez a yudarle. Y por esto, a cabo de veynte días o un mes, bolvió este por allí una madrugada y llegó a la casa del dicho Pero López, qu está pegada a la venta, y llamó e se lebantó e abrió a este; y le dixo a este que allí avía unos costales, que se hechase allí. Y así se hechó y el dicho López estava hechado allí, vestido, y este le tomó su miembro con la mano e le hizo la puñeta y él a este; y este se llegó al dicho López para que se subiera enzima. Y el dicho López no quiso, diziendo que la puñeta en ora buena, pero que lo demás no quería por delante; e que qualquier bellaquería consentería, e besar, pero que [no] ponerse enzima d'este por delante. E qu este entendió que dezir «otra qualquier vellaquería», sí era querer cavalgar por detrás a este, y este se desvió d’él y no pasó más.

Ítem dixo que en la villa de Alcoy está un moço que se dize Joan, criado de Mira, xabonero de Ontiniente, y está de presente en la dicha villa de Alcoy con sus padres, cuyos nombres no sabe. Agora un año, por el tiempo de la seda, estando en la güerta, viniendo este de oýr misa del monesterio de las monjas, dixo a este que le fuese a yudar a coxer oja. Y, estándola cogiendo, este tomó el miembro veril del dicho Joan con la mano y no pasó entonces más. Y luego, otro día, el dicho moço fue a la posada d'este e le llebó un poco de tozino e pan y este le tomó el miembro e le hizo la puñeta este al moço. E después bolvió a la posada de este a cabo de siete o ocho días, de noche, y este le tomó en la mano su miembro y el dicho Joan a este y 
se hecharon en el suelo los dos, el uno enzima del otro, por detrás, desatacados. Y el dicho Joan se puso primero debaxo y este enzima e no le pudo cavalgar. Y luego el dicho Joan se puso enzima d'este y no le cavalgó ni metió el miembro en el culo d'este, más de hechar simiente entre las piernas d'este, porque no pudo, aunque hizo diligencias por meter el miembro.

Y que suplica a sus señorías que se dilate hasta mañana, porqué está fatigado e recogerá su memoria. E llorando dixo: «si yo tuviera de bever y si tubviese medizina en esta botica para mí». E con esto fue buelto a su cárcel y el alcaide le llebó (Img.79-89).

Amador, esgotat, va suplicar posar fi a l'interrogatori. Podem suposar que estava dèbil o malalt, atés que va demanar medicines als seus interrogadors. Atenent les peticions d'Amador, doncs, els membres del tribunal decidiren concloure la sessió. Amb tot, al llarg d'aquell interrogatori Molina no va confessar el crim pel qual fou detingut, i, malgrat que va oferir al tribunal una llista de quinze casos més d'afers sexuals amb homes, aquests es limitaven, com els declarats anteriorment a Ontinyent, a masturbacions, actes maldestres i vessaments seminals externs. Tots aquests fets eren reprobables segons la Inquisició, però, com veurem més endavant, els membres del tribunal consideraven que l'acusat no estava confessant la veritat. En aquest sentit, més enllà d'esperar d'Amador la confessió de l'acte pel qual va ser detingut, el tribunal considerava que, en tots els altres casos declarats, Amador no havia sigut sincer, sinó que hauria consumat plenament l'acte sexual, almenys en alguns dels passatges relatats.

Així les coses, el 27 de febrer de 1588 Amador compareix de nou davant el tribunal. En aquella ocasió tampoc no va declarar res sobre l'afer amb el jove Joan Baptista Alemany; no obstant, afegeix:

Que abrá un año, estando este en Ontiniente en su casa, también tocó sus vergüenzas a Luís, moço de Ayelo, el qual Luís es trabajador que suele entrecavar con Martínez de Ontiniente, y dará raçón d'él [Ro]drigo, moço qu está en Ontiniente.

Ítem dixo que abrá un año poco más o menos, qu estando este en el lugar de Alfarracín, una noche, estando este en el mesón, estava tanbién allí otro moço llamado Budinet, qu está sienpre allí y, a lo que entiende, está con el señor del dicho lugar o en El Ginovés; el qual Budinet llamó a ste y le dixo que fuesen a su casa, y este se fue con él y estubieron los dos un rato juntos. Y este le tocó sus bergüenças y el dicho Budinet cavalgó a ste por detrás, aunque no le metió el miembro, sinó entre las piernas, y derramó simiente, y que no a pasado otra cosa con el dicho Budinet.

Ítem dixo que un mes antes de lo que arriba tiene dicho, estando este en el dicho lugar de Alfarrazín, una noche, estando este [en] el dicho mesón, estava allí un honbre moço llamado Perot, que tiene madre junto a la tienda del lugar, y este y el dicho Perot se salieron del mesón y se fueron a unos pajares y el dicho Perot cavalgó a ste por detrás, sin le meter el miembro, sino entre las piernas, y no sabe si derramó simiente y que no se acuerda si a hecho otra cosa con el dicho Perot.

Ítem dixo que abrá año y medio, estando este confesante en Ontiniente, una noche, estando este en Ontiniente en el mesón, dormían en un pajar juntos este y Juan Grao, trabajador que bive allí en Ontiniente, y este le tomó sus vergüenzas en la mano y se las remeçía, lo qual sentía el dicho Juan Grao y no le respondía nada.

Ítem dixo que en la ciudad de Origüela, abrá cinco o seis meses, que este estava una noche en la plaza y pasaron dos honbres llamados el uno Gracia [sic] Hernández, que ss un honbre alto barvirojo, y el otro Juan Espadador, que posa en el mesón del Manco, que es un honbre 
pequeño, que agora enpieza a barvar y los dos son granadinos; los quales dixeron a ste que fuese a su casa y este fue con ellos. Y para este y el dicho Juan hicieron una cama abajo de la casa, en tierra, con una estera y una manta. Y el dicho García se subió arriba con una muger que este no sabe si era suya. Y durmiendo juntos este y el dicho Juan, se lo hiço a ste por detrás, apretando las piernas, una vez, aunque no metió su miembro en el culo, sino entre las piernas, y allí derramó simiente y no pasó más aquella noche.

Ítem dixo que luego, otro día, llamó a ste el dicho Gracia, que era el otro conpañero, y le dixo que fuesen a su casa y este fue con él y subió a ste arriba y cavalgó a ste por detrás, sin meterle el miembro, açiendo meneos entre las piernas, mas no se acuerda este si derramó simiente. Ítem dixo que en lugar de Cox, legua y media de Origüela, un moçico morisco que bive cerca de la casa del clérigo, que no sabe su nombre más de que tiene padre y madre y será de edad de diez y ocho años poco más o menos, qu es un moço rubio, delicado, de pocas carnes; la tarde de aquel día, este, en la güerta del dicho lugar, le tocó sus vergüenzas y el dicho moço, como bio qu este se desatacó, le cavalgó por detrás entre las piernas, sin meter el miembro en el culo d'este, y no hiço nada; y si lo hiço, este no lo sintió. Y a la noche este se hechó a dormir en un carro, porque allí no ay mesón, y vino allí al dicho carro el dicho moço y como vio a ste fue a llamar a otro moço morisco, que no le sabe el nombre, más de que bive más allá de la iglesia, en la propia acera, en una casa grande, nueva, que el dueño de la casa es morisco y tiene dos hijos y el mayor d'ellos fue el que llamó el dicho moço rojo. Y venidos los dos al carro dónde este estava, el que de nuevo venía subió al carro con este y el otro se quedó abajo. Y al cabo de un rato se fue y quedaron este y el dicho morisco solos. Y luego, el dicho morisco tomó a ste la mano y se la puso en sus vergüenzas, estando este desnudo. $\mathrm{Y}$, alçando el dicho morisco la ropa, se hechó con este y por detrás metió su miembro por entre las piernas, sin se le meter dentro del culo; cavalgó a ste y no sabe si hechó simiente. Y no pasó otra cosa más de que luego se fue y, de allí a un rato, bolvió con otros ocho o nueve moriscos y este se vistió y se fue de allí y así se fueron todos. Y este, a la mañana, conoçió la casa y al moço, viéndole entrar y salir en ella.

Ítem dixo que en el dicho pueblo de Cox, Jayme Dordó, espartero, viniendo con este de Callosa al dicho lugar de Cox, a la que anochecía se metieron en un barranco y el dicho Jayme Dordó cavalgó a ste por detrás, apretando este las piernas de manera que el dicho Jayme Dordó pensava que lo tenía dentro del culo, mas no lo metió dentro, sino que allí cunplió, derramando simiente.

Y después d'esto, otra bez en Origüela, el dicho Jayme Dordó tubo parte con este, cavalgándole por detrás de la mesma manera. Y esto pasó antaño, por el tiempo de los melones.

Ítem dixo que nel lugar de la Granja, junto a Cox, abía un moço de Crevillent llamado Alonso Arrendat. Estando este y él en el dicho lugar de Cox, antes de las uvas, estando bailando en la plaça por unas bodas que abía, el dicho Alonso Arrendat y otro que no le sabe el nombre llamaron a ste y le dixeron que se fuese con ellos a la güerta, y este fue. Y el dicho Alonso Arrendat cavalgó a ste por detrás una vez sin metelle el miembro en el culo d'este porque, apretando este las nalgas, pensava que lo tenía dentro, y derramó hechando simiente. Y el dicho Alonso Arrendat habló con el conpañero y no quiso hacérselo a ste y se fueron cada uno de por si, y este tanbién se bolvió solo a Cox, adónde baylavan.

E que, aunque se acuerda otras cosas que confesar, por ser tarde y no ay lugar, las dirá en la primera audiençia. Y con esto fue mandado bolver a su cárçel (Img. 90-97).

Durant aquesta sessió d'interrogatoris, l'acussat continuava declarant nous casos, també aquests referents a actes sexuals no plenament consumats on Amador rarament n'era l'agent actiu de la penetracio; i, si ho era, mai no consumava per raons com «porque se le doblaba el miembro». Així 
doncs, l'endemà mateix, 28 de febrer de 1588, continuaren els interrogatoris i, durant l'audiència del matí, els inquisidors insistiren:

Vino a ella de su cárcel el dicho Amador Molina, al qual fue dicho que 'n la audiençia pasada dixo que tenía más que deçir y no lo dixo por ser tarde, que diga la verdad y descargue su conçiencia.

Dixo que estando este confesante abrá ocho meses en un lugar que se llama La Onbría o La Solana, qu es de los frayles de Baldigna, estava en el mesón y estava allí un morisco moço llamado Rico, qu es de allí, del dicho lugar. Y el dicho morisco y otro qu estava allí, que no lo sabe el nombre, conbidaron a ste a bever y, después de aber bevido, este se ajuntó al dicho morisco Rico y le tocó sus vergüenzas con la mano y le hiço la puñeta, y no sabe si lo vio el otro morisco, porque era de noche. Y no pasó otra cosa ni hiço aquello más de una bez.

Ítem dixo que en la villa de Elche, d'este reyno, abrá un año qu este fue allí y en la entrada del arrabal de los moriscos, enfrente de la mesma puerta, junto a una tienda qu está allí en la mesma calle, y es de frecería la tienda, bive un morisco que no le sabe el nombre ni cuyo hijo es, más de qu es alto y gordo de cuerpo y será de veynte a veynte y dos años y tiene la madre alta de cuerpo, gorda y morena, con el qual y dicho morisco, topándose este en la güerta de Elche, en el campo, este se puso en el suelo boca abajo y quitados los çaragüelles. Y el dicho morisco se puso enzima d'este y le cavalgó por detrás, aunque no le metió el miembro en el culo, más de que le hechó simiente entre las piernas. Y que fue sola esta vez y no a pasado otra cosa con el dicho morisco.

Ítem dixo que en la dicha villa de Elche, en el mismo tienpo que tiene dicho, andando este por la güerta que tiene dicho, se topó con un morisco cuyo nombre no sabe, ni su casa ni quién sea su padre, más de qu es un moço flaco, alto y no le bio más qu esta vez. Y juntándose los dos, este le hechó mano a sus vergüenzas y le hiço la puñeta una bez, y no pasó otra cosa.

Ítem dixo qu estando este en el lugar de Crevillente abrá un año, dende allí fue a Callosa y se topó en el camino con un morisco, hijo de otro que se llama Sanítos[?], que a la saçón era carnicero en Almoradí y agora está en Crevillente, qu es un moço rubio, baxo de cuerpo, de asta veynte años, que se llama Joan. Y este en el mismo camino le tomó sus vergüenzas en la mano y hiço la puñeta una vez y no pasó otra cosa.

Ítem dixo que por el mismo tienpo que tiene dicho, yendo este de Albatera a Crevillent, se topó en el camino con un morisco que no sabe otras señas que dar d'él, más de qu es honbre pequeño de cuerpo y tiene un cuñado qu entonces era cortador de carne en Callosa y tiene los ojos malos. Y, abiéndolos hablado en Callosa, de antes se conocían. Y el dicho morisco y este se asentaron en el canpo y, después de aver hablado un rato, el dicho morisco cavalgó a ste por delante, estando los dos desatacados, metiendo a ste el mienbro entre las piernas, apretándolas este, y le hechó simiente una vez y no pasó otra cosa. El qual morisco dio a ste una granada de las que llevava para una persona suya, que no la sabe el nonbre, más de que es la muger del carnicero que tiene dicho.

Y que por agora no se le acuerda más, que él se acordará qué más tiene que deçir porque a hecho mucho mal a su Dios. Y amonestado que prese en descargar su conçiençia enteramente, fue mandado bolver a su cárçel (Img. 98-102).

El següent testimoni conservat va tindre lloc el 3 de març de 1588, durant l'audiència de la vesprada. Aquest és l'últim testimoni que ens ha pervingut d'Amador, abans de l'acusació del fiscal. En aquesta ocasió, novament, no farà esment dels fets que motivaren la seua detenció a Ontinyent, però continua engrossant la seua llista delictiva: 
Dixo que en un lugar que se dize Novelda, del reyno de Balençia, dos leguas más allá de Helda, qu es lugar de moriscos, pasando por cerca de allí, este se encontró en el campo, junto al lugar, con un hijo o criado de Borriquí el Viejo, morisco, vezino de el dicho lugar, cuyo nombre no sabe ni determina si es hijo o criado de el dicho Borriquí, aunque él dixo a este que hera hijo, qu es un moço colorado, ruvio, desbarbado, pequeño, de hasta beinte años. Y estubieron juntos un rato hablando. E luego, este le tomó sus bergüenças con la mano y el moço dixo a este que se fuesen a un huerto qu estava allí çerca para cavalgar a este. Y este le dixo que no quería yr por no se fiar d'él. Y ansí, en pie el uno y el otro, quitados los çaragüelles, el dicho moço se arrimó a este y, entre las piernas, por detrás, cavalgó a este sin meterle el miembro más de que hechó simiente entre las piernas, e que no pasó más e que fue una vez sola. Y que el dicho Borriquí el Viejo, qu es padre o amo d’este moço, tiene la casa más acá de la plaça, subiendo del Pilar la calle arriba, en una esquina, a mano derecha, la primera o segunda casa, lo qual dize porque ay otros d'este mismo nombre de Borriquí; e qu esto abrá que pasó un año poco más o menos. Preguntado, dixo que no le dio nada a este ni se lo pagó.

Ítem dixo, que en Pretel [sic], más arriba de Elda, ay un moço que se dize Martín, morisco, hijo de una biuda, que no le sabe otro nombre, qu es un moço gordo, redondo, blanco, de mediana estatura, quebrado de color, con el qual este se topó en una viña, abrá un año poco más o menos. E, después de aver estado sentados hablando un rato, este le tocó sus bergüenças al dicho moço, el qual cavalgó a este una vez solamente, quitándose este los çaragüelles y el otro tanbién e poniéndose este boca abajo y el dicho moço enzima d'este. Pero que no le cavalgó metiendo el miembro en el culo d'este, sino entre las piernas de este. Derramó la simiente pensando el dicho moço que lo metía dentro del culo d'este. E qu esto pasó una vez sola y no pasó otra cosa ni le dio a este nada por ello.

Ítem dixo que en la villa de Aspe, estando junto al pueblo, en un sequero de pasas, se encontró este con un moço cuyo nombre no sabe, ni el de su padre, más de que bive yendo de Novelda al dicho lugar de Aspe, en unos corrales antes de llegar al pueblo, a las espaldas de un espargatero, que no sabe otras señas, e que es moço alto, delicado e que su padre tiene un par de mulas e una somera y qu es la casa como detrás los corrales, a mano ysquierda. Y aviéndose quedado este a dormir en el dicho sequero, el dicho moço fue adónde este dormía, de noche, y tubo quehazer con este, y le cavalgó dos vezes en diferentes días. Y a la segunda vez llevó este moço consigo otro, que hera el alpargatero que tiene dicho, cuyo nombre tampoco le sabe ni el de su padre, que será moço de hasta diez y ocho o beinte años. E que lo que pasó fue qu estando este desnudo, el dicho moço se puso enzima d'este y le cavalgó sin meterle el miembro, sino que hechó la simiente entre las piernas d'este una vez sola este, qu es el alpargatero. Y el otro moço, dos o tres vezes enzima d'ellos, le metió el miembro sino entre las piernas, hechando simiente. E que el primero le dio un pedaço de torta de paniço y el alpargatero no le dio nada. Y no pasó otra cosa.

E que con otros diez o doze moços le a conteçido lo mesmo, cavalgándole de la misma manera, aunque ninguno le a metido el miembro, sino entre las piernas, e que ninguno d'estos le a dado nada, ni se acuerda al presente ni sabrá dar señas d'ellos ni de adónde heran, porqué los ha topado en diferentes partes en el campo, que le pareçe que, si le llevasen, atinaría con ellos. Y que no se acuerda agora más que dezir, que si se lo acordare, él lo dirá (Img. 102-106).

Finalitzada aquesta declaració i al llarg de la mateixa sessió, el tribunal va amonestar, de nou, Amador i li advertí que el fiscal pensava presentar una acusació contra ell i, per tant «se le amonesta que, antes que la presente, diga la verdad porque le aprovechará mucho para la salvaçión de su alma y breve despacho de su causa» (Img.109). Llavors, Amador va tornar a respondre que no recordava 
res més. Per tant, sense la confessió que buscava, el fiscal del Tribunal de la Inquisició de València va presentar contra ell la seua acusació criminal:

porque, siendo cristiano baptiçado y tal se nombrado, con grande escándalo del pueblo cristiano y peligro de su ánima, ha comettido y perpetrado grandes y atroçes delictos, cuyo conoscimiento, punición y castigo pertenesçe a este Santo Officio. (Img. 109)

D'aquesta extensa acusació del fiscal on enumera un per un tots els crims, tant els confessats per Amador com els que no, extractem els punts referents a aquests darrers, això és, aquells que tenen a veure amb la causa de l'inici del procés:

\begin{abstract}
1 Espeçialmente, el dicho Amador de Molina, en un barranco qu está junto a una montaña, entre la venta de Viar y la villa de Ontinenti, obstrapó a un muchacho llamado Joan Baptista Alemán, por fuerça y con engaños, y cometió con él el delicto nefando de sodomía, metiendo su miembro viril dentro del culo del dicho muchacho, haciendo meneos y forcejando para, con todo effecto, consumar el dicho delicto.

2 Y para cometer el dicho delicto más a su salbo, engañó al dicho muchacho y, antes de día, lo sacó de la venta de Biar y, descaminándole del camino Real, por fuerza comettió con él el dicho delicto.

3 Y después, encontrando el dicho muchacho a çiertas personas, las quales la noche de antes habían estado en la dicha venta de Biar, se quejó con grande sentimiento de la fuerza y daño que 1 dicho Molina le había hecho. Y con esto, la justicia de Ontinenti luego prendió a los dichos Amador de Molina y muchacho y de las cárçeres de Ontinenti an sido traýdos presos. Y el dicho muchacho es el mismo con el qual ha comettido y perpetrado el dicho delicto, el qual supplica a V. M. manden que sea visto y reconosçido por los cirujanos d'este Santo Officio (Img. 109-110).
\end{abstract}

La resta de crims que acumula l'acusació provenen, en gran mesura, de les pròpies declaracions d'Amador. El fiscal, doncs, a banda d'acusar-lo de forçar Joan Baptista Alemany, incideix en el fet que «Amador de Molina es tan aviçiado y disoluto en cometer con muchas personas, en diferentes veces y lugares, delictos nefandos de sodomia» (Img. 110-111) i recull tots els actes homosexuals, consumats o en grau de temptativa, que Amador ha anat relatant al llarg dels seus testimonis. En aquesta llarga llista, sempre que això és possible, el fiscal aporta la identitat de les persones amb qui Amador va tindre relacions sodomítiques; a saber: Julià, de Castelló de Rugat; Pere Esparça, de Vallada; Antoni Torres, l'aprenent de cadirer; «en la venta de Biar [...] dos hombres que se habían acostado cabe él», que són l'aragonés i el de Chinchilla; Joan Lescano, d'Ontinyent, porter i pretendent de la filla d'Amador; Miguel Muñoz; Luis, de l'Olleria; un morisc de Vilallonga que venia vidre; Pedro Richarte, de Biar; un mosso anònim d'Ontinyent; Agustí i Alonso, d'Alcoi; dos moriscos de Castelló de Rugat; Rafael, de Banyeres de Mariola; Andrés, de Biar; Joan, d'Alcoi; dos mossos de nom Vicent i Julià; Pere Llopis, de Biar; Luis, Morisco d'Aielo, Joan Grau, d'Ontinyent; Budinet i Perot, d'Alfarrasí; Garcia Hernández, d'Oriola; Jaume i un altre anònim, de Cox, tots dos moriscos i Lluís Aranda, de la Granja. Tot i això, el fiscal acaba l'acusació afirmant que:

Ha cometido otros semejantes delictos que prometió especificar en la prosecuçión d'esta causa y muchos por V. M. a ssido amonestado muchas y diversas veçes para qu él en todo diga y confiesse la verdad enteramente, y no lo ha hecho y como mal cristiano se ha perjurado (Img. 115). 
Llavors, encara sense la declaració jurada d'Amador, el fiscal demana:

que, siendo neçesario, el dicho Amador de Molina sea puesto a qüestión de tormento, en el qual este se persebere y en su persona se repita asta que d'él s'entienda la verdad, para lo qual y en lo necesario, el officio de V. M. imploro, pido justicia (Img. 115-116).

Hem d'entendre aquesta «qüestión de tormento», no com una pena imposada, sinó com un mitjà per obtenir la prova definitiva, això és, l'esmentada declaració jurada, i poder finalment conèixer la veritat dels fets. No obstant, davant d'aquesta relació del fiscal, Amador va respondre a cada punt de l'acusació (Img. 116-122), bé matisant els fets, bé acceptant-los plenament com a certs; però en cap cas va admetre haver mantingut relacions sexuals amb Joan Baptista Alemany. Respecte a aquest punt, la resposta d'Amador va ser contundent: «Dixo que si el día del Juicio Dios no le pide otro pecado si no es este del muchacho, que no tenia ninguno, porque se lo levanta y así lo niegue» (Img. 116).

Per tant, el judici havia de continuar, i ho feia el mateix dia 4 de març de 1588, en la sessió de la vesprada. Segurament, l'amenaça del turment -si no l'aplicació d'aquest- va influir en les següents rectificacions d'Amador. Ara els actes sexuals relatats ultrapassen els simples jocs eròtics més o menys maldestres que havia declarat en anteriors sessions, tot explicant que, efectivament, en molts casos hi va haver penetració consumada i explicitant la durada d'aquesta; a més d'afegir altres actes que, segons Amador, ja havia declarat, per bé que el fiscal no els hi hagués inclòs a la seua relació acusatòria. La nota marginal d'aquest foli explica que Amador «Empeçó a añadir y confessar consumación del delicto con muchos» (Img. 122):

\footnotetext{
Dixo que con aquel moço de Pretel [sic] que tiene confesado, lo que pasó en berdad es que, quando cavalgó a este el dicho moço, le metió parte del miembro, como la mitad, y que no sintió que le hechase la simiente dentro. Y lo mesmo pasó con otros dos moços de Aspe que tiene confesado, los quales metieron parte del miembro en el culo de este, que no se acuerda si le hecharon simiente. Preguntado, dixo que cada uno d'estos tendría el miembro en el culo de este por espaçio de un Credo, poco menos.

Ítem dixo que aquel moço que le cavalgó de la Granja, junto a Cox, llamado Aranda, metió en el culo d'este el miembro y echó simiente dentro. Y también el otro moço que tiene confesado, llamado Jayme Dordó, de Cox, le metió el miembro dentro del culo d'este, y que no sintió si le hechó simiente dentro e que tenía el dicho miembro dentro del culo d'este muy poco espaçio, que sería como tiempo de un Ave María.

Ítem dixo que también el otro moço de Cox, ruvio, que a dicho que no le sabe el nombre, así mesmo metió el miembro dentro del culo d'este e que no sintió que le hechase simiente e que le tendría el dicho miembro dentro, espaçio de un Ave Maria, por el recelo que sentían de no ser vistos, porque estavan en el campo.

Ítem dixo que el otro moço de Cox, cuyo nombre no sabe ni más señas de las que tiene dichas y confesadas, que es hijo de un hombre rico que bive en una casa nueva junto a la yglesia y es el hijo mayor de dos que tiene, puso el miembro junto al sieso del culo d'este y mojó el miembro con saliva y forcejó para metelle y este no lo consintió porque tenía grande el miembro.

Ítem dixo que el uno de los moços que tiene confesado de Crevillente, que es el cuñado del carniçero de Callosa que tiene dicho, metió su miembro dentro del culo d'este e no sintió que le hechase simiente y le tenría dentro el tiempo que los demás que a dicho en esta audiençia, Ítem dixo que otro moço de la Granja, del qual hasta agora no tiene dicho, cuyo nombre no
} 


\begin{abstract}
sabe, ni más de qu es un moço ruvio, de mediana estatura, de hedad de hasta beynte años, cavalgó a este detrás de un pajar en el campo, agora un año, una bez sola, y metió el miembro en el culo d'este y no sintió simiente dentro. Y le tenría dentro en el culo el tiempo que los demás que tiene dicho en esta audiençia.

Ítem, en la dicha Granja, otro moço que no le sabe el nombre ni cuyo hijo es, más de que es moço alto de hasta beinte años, moreno, dixo a este que le cavalgaría si este le dava a él quatro reales primero; y este, aunque los tenía, no se los quiso dar ni le cavalgó, más de que puso su miembro en las manos d'este.

Ítem dixo que agora se le acuerda que en Albatera, un moço que se llama Alonso, cuyo nombre no sabe más de que fue a Murçia a llevar unas cartas del señor de Albatera, a don Enrique, a Murçia, que no le sabe otro nombre más de don Enrique, e qu esto abrá un año, poco más o menos, el qual, viniendo juntos este y él de Murçia a Albatera, en el camino, el dicho Alonso cavalgó a este una vez sola, metiéndole su miembro en el culo d'este. Y no se acuerda si hechó simiente e que le tenría dentro como un Credo, e que no le dio nada a este por ello. E que ansî mesmo, en Albatera ay algunos otros que le an cavalgado, cuyos nombres ni señas no sabe. E que el uno metió el miembro dentro del culo d'este e no sintió si hechó simiente e que lo tenría dentro como un Credo.

Ítem dixo que biniendo este de Murçia, abrá año y medio, otro moço benía delante d'este por el camino e se sentaron junto a una açequia y el otro puso a este la mano en la abertura de los çaragüelles de este y este también le puso la mano en sus bergüenças. Y este le dixo que para qué haçía aquello; e le dixo que se olgava de tenerlo en las manos y que avía estado en Aragón con un cavallero que tenía criados e que no le dixo quién hera, el qual le avía dado un vestido porque le cavalgava, e que no sabe el nombre del moço ni dónde bive e que por agora no se acuerda de otra cosa. E con esto fue mandado bolver a su cárcel y el alcayde le llebó (Img. 122-127)
\end{abstract}

Pocs dies després, durant la sessió del 9 de març de 1588, el Tribunal de la Inquisicó va presentar misser Sánchez Sisternes com a advocat procurador d'Amador de Molina. Aquest «prometió de ayudar e defender en esta causa e proceso al dicho Amador Molina e que usará de las defensas permitidas por derecho, e que guardará secreto» (Img. 128). El fiscal, per la seua banda, acceptà les confessions d'Amador en aquells punts que li eren favorables, «e no en más, negando lo perjudicial» (Img. 129). Amb la relació de testimonis enllestida per part del fiscal, el tribunal donà per finalitzada la part sumària del procés, sobre la qual va exposar que «concluya e puede ser recibido a la prueva» (Img. 129). Com que la confessió d'Amador no s'havia produït -almenys la que el culpabilitzaria d'haver abusat de Joan Baptista Alemany- la prova que, d'acceptar-se com a vàlida, condemnaria Amador, era la relació de les declaracions dels implicats que conformaven la publicació de testimonis presentada pel fiscal. En relació amb aquest darrer punt, l'endemà, 10 de març de 1588, Amador elegí per procurador seu Onofre Barberà, familiar de la Inquisició d'Ontinyent, perquè s'ocupés de «ber jurar e conocer los testigos que por parte del fiscal serán presentados contra él» (Img. 131). Per la seua banda, i amb la mateixa finalitat, el fiscal elegí Jeroni Colomer, familiar, i Jaume Romeu, un dels dos encarregats de detindre Amador el dia dels fets.

La llista d'homes amb què Amador havia mantingut algun tipus de relacions sexuals era llarga i tots ells eren, a priori, culpables del mateix delicte de sodomia. Per aquest motiu els inquisidors 
procuraven que la informació sobre ells fóra el més completa possible. Si Amador desconeixia el nom, aportava totes les descripcions possibles que permeteren la Inquisició localitzar l'individu en qüestió. D'aquesta manera, a més d'aportar-los com a testimonis en la causa d'Amador, se'ls obria un procés propi paral lel, del qual s'extractaven les parts adients i s'incorporaven a l'expedient d'Amador. D'aquestes declaracions extractades d'altres processos i incorporades al d'Amador se'n conserven tres. La primera pertany al procés de Pedro Richarte, de Biar, del dia 16 de març de 1588:

hijo de Gaspar Richarte, de la villa de Biar, e qu este es labrador y que bivía agora en la venta de Viar con el amo d'ella, que se llama Andrés López, y que le servía de labrador y este és moço por casar y que es de edad de veynte y un años y que anoche trajeron preso a este Santo Officio. Preguntado si sabe o presume la causa por qué a sido traýdo preso, dixo que sí señor, y que presume que biene preso por un hombre cuyo nombre no sabe más de haber oýdo dezir que se llama Molina, que es un hombre que paresce mulato que, piensa, bive en Ontiñente y que lo que pasa es que en el tiempo del sembrar del año ochenta y siete, el dicho Molina, mulato, pasando por la venta dónde este estava con dos mugeres, que él decía, era la una su muger y la otra su hija, y que se iva a bivir a Ontiñente y entonces se hablaron y quedaron conocidos. Y después, dentro de un mes, el dicho Molina solo vino a la venta y, una noche, estando este durmiendo en casa de su amo, qu está junto a la venta, fue allá y entró dónde este estava durmiendo, y se hechó a dormir junto a este. Y estando hechados los dos, el dicho Molina tomó con la mano el miembro d'este y este le hechó la mano para tomar el suyo y no lo hiço porqué no osó. Y luego, el dicho Molina se desatacó los çaragüelles y desiço a este la çinta de sus çaragüelles y se puso buelto de ancas a este y le asió con la mano y este entonçes, como le vio de aquella manera, se levantó y se fue y el Molina también y que no pasó otra cosa más d'esto y que es la verdad por el juramento que tiene hecho.

Pasó ante mi, Francisco Gutiérrez, secretario. Sacóse del proceso del dicho Pedro Richarte. Concuerda con su original por mi, Nicolás del Rio, secretario (Img. 45-47).

El segon document procedent d'un altre procés paral lel s'ha conservat incomplet. Es tracta de la declaració de Pedro Alache, d'Asp. Aquest, juntament amb Gaspar Herrimén, també d'Asp, havien estat detinguts per mantenir relacions amb Amador al castell d'Asp:

[...]se quedasen con él en el dicho castillo y no lo querían haçer. Y estando en esto, el dicho negro dixo a este si quería hoder y este entonzes no quería entrar; y, en fin, le çegó el diablo y entró en un aposentillo adónde estava el dicho hombre moreno y estando desatacado y desnudo, este se puso ençima d'él y metió su miembro viril en el culo del dicho negro hombre moreno y le tubo dentro asta que hechó simiente y consumó el dicho acto de sodomía con todo efecto, hechándole la dicha simiente dentro del culo al dicho hombre moreno, y que solamente una vez cometió el dicho delicto.

Item dixo que acabado este confesante de cometer el dicho delicto, el dicho Herrimén, su amigo d'este, entró luego en el aposentillo adónde estava el dicho hombre negro y estubo con él otro tanto tiempo como este estubo.

Preguntado, dixo que el dicho Herrimén este no sabe que cavalgase al dicho negro, ni le vió entrar ni salir quitadas las calzas en el dicho aposento, ni después que salió yéndose, como fueron juntos a sus casas, ni este le dixo nada de lo que había hecho ni el dicho Herrimén a ste, más que, como tiene dicho, entró en el dicho aposento el dicho Herrimén y estubo con el dicho hombre moreno, a quien dió el dicho Herrimén un pedazo de pan, atendiendo qu era pobre y que aquel no era hombre sino diablo.

Preguntado, dixo que el dicho Herrimén es un moço que empieza a barbar, blanco de color, alto de cuerpo, aunque no mucho, pero más qu este confesante, y que es labrador; y que su 
padre, Rodrigo Herrimén, también es labrador y vive junto al camino de Balençia d'esta parte del rio de Aspe, y que esto es lo que al presente se le acuerda y lo que pasó (Img. 43-44).

El darrer extracte incorporat d'un altre procés prové del de l'adés esmentat Gaspar Herrimén, igualment incomplet:

[...] ençima d'él, quitada la çinta de delante de los gregescoles y le cavalgó metiéndole su miembro viril dentro del culo del dicho negro, y le tubo dentro asta que allí dentro del culo derramó simiente, aunque al acabar, parte de la simiente hechó fuera del culo del dicho negro porqué este lo haçía contra su voluntad, aunque bien cree y tiene por çierto que parte de la simiente quedó dentro del culo del dicho hombre moreno, y que la substancia que tiene dicho consumó y perpetró el dicho delicto, y pide misericordia y penitencia porqué el dicho hombre moreno le persuadió a que lo hiciese, y que una vez solo lo hiço con el dicho moreno.

Preguntado, dixo que ni con el dicho hombre moreno ni con otro no a cometido el dicho delicto ni otro ninguno, más de solo la vez que tiene confesado. Y que el dicho castillo dónde cometió el delicto que tiene dicho está algo desviado del lugar de Aspe y no le abita nadie; y así, aunque era de día, pudieron cometer el dicho delicto sin que nadie les viese. Preguntado, dixo que no sabe que otra persona aya cometido el dicho delicto con el dicho hombre moreno, y que por cometer el dicho delicto que no dio cosa ninguna al dicho hombre moreno, y que de lo que cometió está muy arrepentido y pide perdón y que para esto a pedido audiençia, y es la verdad por el juramento que tiene hecho y con tanto aviéndole advertido que piense en el descargo de su conçiençia. Fue mandado bolver a su cárçel y se reservó la primera moniçión para mañana por ser domingo (Img. 51-52).

No sabem la data de les declaracions de Gaspar Herrimén, però el procés conserva l'acta de la confrontació entre testimoni i acusat, el careo, mantingut entre Herrimén i Amador el 26 de març de 1588, quan el fiscal comunica a Herrimén que el presenta com a testimoni en el procés contra Amador. Ja hem fet notar a la introducció d'aquest procés com aquesta confrontació entre testimoni i acusat és una de les diferències més notables entre els judicis per sodomia i la resta de causes de Fe, perquè d'aquesta manera es feia pública -almenys per a l'acusat- la identitat d'aquells que testificaven contra ell, acte aquest exclusiu de les causes de sodomia. L'hermetisme tradicional, doncs, dels processos inquisitorials deixava pas a escenes com aquesta:

En la audiençia de la mañana de la Santa Inquisición [...] fue mandado traer al dicho Gaspar Herrimén, y siendo su dicha audiençia, fue mandado traer también al dicho Amador de Molina [...] Preguntado si conoçía al dicho Amador de Molina, dixo que le conoçía; y así mesmo fue preguntado al dicho Amador de Molina si conoçía al dicho Gaspar Herrimén, y dixo que le conoçía. Y con esto fue buelto a su cárçel el dicho Amador de Molina. Fuele dicho que 1 del Santo Oficio le presenta por testigo en el pleyto que trata contra Amador de Molina (Img. 53).

A grans trets, el procediment inquisitorial permetia que, fins que no es publiqués la sentència final, l'acusat pogués confessar el crim, penedir-se dels fets i -si no era reincident- reconciliar-se amb l'Església; amb la qual cosa, si es reunien aquests requisits, la condemna rarament acabava amb l'execució de la pena capital. Per aquest motiu, l'acusat podia demanar audiència i seguir afegint confessions. No obstant, pel que fa als casos de sodomia, una declaració inculpatòria que provara fermament el delicte podia implicar l'aplicació de la pena reservada als sodomites, això és, la mort. 
En qualsevol cas, permetia despatxar la causa. En aquest context, el 27 d'abril de 1588 la Inquisició concedí audiència a Amador, en la qual:

Dixo que es verdad que él ha dicho que tiene que descargar su conciencia. Y es que abrá algo más de un año, durmiendo este en un pajar del mesón qu está en la plaça de Algemesí, en la squina, con un moço morisco que bendía xabón, que dixo ser natural de Xàtiva, que será moço de mediana estatura, enxuto, flaco, moreno de rostro, pocas barvas y que trae solo una bestia con el xabón, y es muy conocido de la mesonera. Y suele dexar xabón para que se lo guarde o venda; y la mesonera era biuda; que este no le sabe el nombre ni cuyo hijo era, más de que entendió era de Xàtiva e de la huerta de Xàtiva. Y estando en dicho pajar juntos, el dicho morisco cavalgó a ste una vez, metiéndole su miembro viril dentro del culo d'este y que le tuvo dentro por espacio de un Credo y aún no. Y no se determina si le hechó simiente dentro ni fuera.

Ítem dixo, que abrá un año, por el tiempo de los higos, y luego dixo que cumplirá el año a los higos que bienen, estando este en Albatera, este salió para hir al lugar de la Granja y este topó en el camino, delante d'este, en un carro, un moço de edad de hasta diez y ocho años o diez y siete años, que era pequeño de cuerpo, ruvio de cara, y el carro y mulas eran suyas y natural de Albatera. E yva por piedra a una pedrera entre la Granja y Albatera, la qual está a la mano derecha de la Granja. E hizo subir a este en el carro y allí, en palabras que tubieron, vino dicho moço, que era morisco a lo que este entiende, a cavalgalle, metiéndole su miembro viril en el culo d'este, y le hechó simiente dentro del culo y estuvo dentro spacio de un Credo. Y aunque le nombró cuyo hijo era, este no se acuerda ni el nombre suyo, ni sabe otras señas.

Ítem dixo qu estando en Crevillente abrá un año, este trató con otro moço morisco, moreno de rostro, sin barba, que tiene los dientes morenos, y será de edad de diez y siete o diez y ocho años. Estando en un güerto baxo del lugar junto a unas tapias, entre unos árboles, cavalgó a ste dos vezes en diversos días, metiéndole el miembro viril dentro del culo d'este; y no sabe si hechó simiente dentro del culo d'este ni fuera, teniéndole dentro el dicho miembro menos spacio de un Credo, y no se acuerda del nombre del dicho moço, ni cuyo hijo es.

Ítem, que en el mismo tiempo, este trató en dicho lugar de Crevillente con otro moço morisco, de edad de veinte años, bermejo de cara, sin barbas, mal rropado, que no le sabe el nombre, los dientes de arriba claros, cariancho e chico en piernas, en el mismo güerto, detrás de unas çarças y morera, cavalgó a este metiéndole su miembro viril dentro del culo d'este, hechándole simiente, y estuvo dentro como un Credo, y que por ahora no se acuerda de otra cosa, que si se acordare, él lo dirá. Y con esto fue buelto a su cárcel (Img. 69-72).

Malgrat declarar una gran quantitat de casos, el procés d'Amador s'allargava. Així doncs, el 9 de maig de 1588 tornava a demanar audiència per tal de:

suplicar a su señoría le manden leer todas sus confesiones para ver si abrá que añadir, que de quitar no ay cosa ninguna, porqué para aquí y para delante de Dios, que en todo lo que a dicho, a dicho confesando la verdad y si es necesario lo dize de nuevo.

Ítem dijo que también se le a acordado qu estando en Helche, abrá un año, estava allí un morisco vendiendo arroz, el hombre del qual no sabe más de qu es hombre pequeño, de mediana estatura, y será de veynte y cinco años o veynte y quatro, y tiene dos mulas y un asnillo y es de Xàtiva, sigún él dixo a ste. Y siendo ya de noche, este y el dicho hombre, que es morisco, se salieron del pueblo y se fueron al campo, y apartándose detrás de unos montones de sosa, se asentaron tras ellos y de palabra en palabra este y el dicho morisco se desatacaron los çaragüelles. Y este se puso boca abajo y el dicho morisco se le puso enzima y metió su miembro, aunque un poco, en el culo d'este. Y este no sabe si el dicho morisco hechó simiente o si no, más de que estubo como una Ave María enzima d'este y metido su miembro en el culo d'este. 
Ítem dixo que otra vez, estando en Ontiniente el agosto pasado, abía allí un moço que no le sabe el nombre, más de que estaba con amo y no sabe con quién, y es un moço de asta diez y ocho o veynte años, alto de cuerpo y delgado, caripecoso, sin barbas, y traýa unos çaragüelles fraylescos y sin capa, porqué se la avían urtado, y dará razón d’él un amigo suyo, moço, que no le sabe el nombre sinó que está allí con amo y tampoco sabe con quién, más de qu es un moço muy señalado, blanco y tiene en el carrillo una señal de herida, y dezía era de Murçia. E que estando este en su casa, allí en Ontiniente, el dicho moço fue acá y traxo vino. E çenaron los dos juntos y luego dixo que no sabe si el otro çenó. Y en habiéndose çenado, el dicho moço se hechó boca abajo en tierra, abajados los çaragüelles y este se puso enzima, también bajos sus çaragüelles y provó a cavalgar al dicho moço, y no pudo ni hiço cosa ninguna. Y luego el dicho moço, que le pareçe se llama Francisco, se puso enzima d'este y le cavalgó por el culo metiéndole su miembro viril, aunque poco, y no sabe cierto si derramó simiente, que, si él lo dice, será verdad. Y estubo enzima de este como una Ave Maria. Y después este preguntó al dicho moço Francisco si abía hecho aquello con otros ombres y le dixo que sí, que con [a] quel su amigo arriba dicho de la señal en la cara lo abían hecho y no le dixo qual a qual había cavalgado, qu ellos lo dirán.

Ítem dixo que estando este en Alcoy trabajando a entrecavar, trabajava con este dos moriscos hermanos, cuyos nombres no sabe, más de que el uno és alto, barvirúbio y los ojos açules, y trae un capote verde con buelta de terziopelo visto verde; y el otro es moço pequeño, barvihendido, blanco de cara, pocas barvas y tiene en los carrillos un hoyo o dos. Los quales dixeron a ste qu eran dende Oliva asta Alcoy, de aquellos lugares asta Gandia, que no se acuerda de qué lugar. Y el dicho hombre más pequeño tanbién lleva capote verde y con terciopelo la buelta. Los quales, estando este un día en el campo con el más pequeño de los dos hermanos, cavalgó a ste por detrás una vez, metiéndole su miembro viril por el culo y derramando simiente, cumpliendo con todo efecto. Y el otro hermano, aquella noche o otra más adelante, estando en el mesón de Alcoy qu es de Monzón, este y el dicho moço mayor se encontraron en un pajarón y cavalgó a ste metiéndole un poco del miembro viril en su culo d'este, y no sabe si hechó simiente o no porqué no le tubo dentro su miembro más de como un Ave Maria, que él dirá si hechó simiente. E que los dichos dos hermanos són moriscos.

Ítem dixo, qu estando este en Elche, stava allí un hombre extraño, que no sabe cómo se llama ni de dónde es, más de qu es trabajador y es hombre bajito, cuerpo moreno, pocas barbas, diente menudo, roto de vestidos, el qual dezía qu era forastero y este le a visto en Murçia. Y, estando este y el dicho honbre en el campo, cavalgó a ste una vez, metiéndole su miembro viril en el culo d'este, derramando simiente dentro d'él y consumiendo el dicho acto con todo efecto. Y otro día adelante, otra vez, ni más ni menos, con todo efecto cavalgó a ste de la mesma manera.

Y por ser tarde, cesó el audiençia y dixo que tenía más que dezir, que le den otro día audiençia. Y suplicó le manden dar conpañía y más raçión, que se muere de hambre. Fuele dicho que en todo se torna querel[1]ado, y amonestado fue mandado bolver a su cárcel. (Img. 63-68)

La darrera declaració del procés es va produir el 18 de juny de 1588, com les dos darreres, a petició d'Amador. En aquella ocasió va declarar:

que en el lugar de Ibi ay un moço que es hijo de una biuda, el qual llevava a vender harina a Alicante con dos amigos; al qual, estando este en Alicante le conoció. Y después, aora quando vino a segar a Ontinente y durmió en casa d'este [...] un compañero suyo, que es un moço alto, no moreno ni blanco, pocas barvas y será de edad de veinte y un años. Y estando en casa, estando durmiendo, este le tocó sus vergüenzas dos vezes y bino en polución y que no sabe más. 
Ítem, dixo que estando en Elche ará año y medio, durmiendo este en el horno del castillo, un moço que acarreaba tablas de pan, que dixo era de tal ciudad, siendo palero en el horno Soler o Oliver, que era un hombre pequeño, el dicho hombre que acarreaba pan, que era de edad de diez y nueve años, este le tocó las vergüenzas y él a este. Y que este le dixo que cómo hazía aquello. Y él le respondió que la otra vez él lo abía hecho en Valencia. Y que para esto ha pedido la audiençia y que pide se le léan sus confessiones, no para quitar nada de lo que está, sino para ver si se acuerda de algo (Img 60-61).

\section{El final del procés}

No s'han conservat més declaracions d'Amador, per bé que el procés en recull nombroses. En cap de les sessions del seu procés mai no va confessar haver tingut res a veure amb el jove de València Joan Baptista Alemany. Tot i això, el Tribunal havia d'emetre una sentència. Aquesta ens ha arribat acèfala, però conserva els elements més importants de la resolució del tribunal d'inquisidors. En aquesta sentència hom pot llegir:

el dicho Amador de molina, antes de su acusación, dixo y confesó que era verdad que en çiertos lugares d'este reyno y districto que nonbró abía cometido el delicto nefando de sodomía con trenta y quatro personas; que declaró cometiendo dicho delicto con algunos de ellos como paciente y con otros como agente con todo efecto; y con otros, teniendo actos torpes y sodométicos y provocándoles al dicho delicto nefando [...] y en lo que pedían de aver estrupado el mochacho en el barranco, que aquello no pasava tal y que lo negava. $Y$ en otras audiencia que con él se tubieron en el discurso de su proceso dixo y confesó aver cometido el dicho delicto nefando con otros treze moços más de los que tenía confesados [...] unas vezes como agente y otras como paciente, aunque con algunos d'ellos solamente abía abido atentados y actos torpes. A instancia del dicho fiscal mandamos haçer y heçimos publicaçión de testigos; y, siéndole dado d'ello notiçia, dixo que él tenía dicha y confesada la verdad, aunque bien entendía que serían más los moços y mochachos de los que tenía declarados y que no se acordava [...] e que todavía negava el extrupo del mochacho, porque si fuera verdad, lo oviera confesado como a dicho mucho que no le pedían (Img. 148).

En efecte, Amador havia declarat «mucho que no le pedían». Això, junt amb les declaracions de testimonis aportades pel fiscal, era prova suficient per declarar la culpabilitat de Molina, malgrat no haver confessat l'estupre de Joan Baptista Alemany. Amb les proves esmentades, la Inquisició emetia el següent veredicte:

Fallamos, atento los autos y méritos de el dicho proçeso, el dicho promotor fiscal aver provado bien y cumplidamente su acusaçión [...] en conseqüençia de lo qual, que devemos declarar y declaramos al dicho Amador de Molina por perpetrador de los dichos delictos nefandos de sodomía y contra natura. Y como a tal le devemos de condenar y condenamos a que el día que se celebrare auto público de la fe por este Sancto Officio, salga al cadalso en forma de relaxado adónde le sea leýda esta sentencia, por la qual le relaxamos a la justiçia y braço seglar y al excelentísimo señor visorey y capitán general d'esta çiudad y reyno [...] para que le resçiban en su fuero y jurisdicción, a los quales pedimos con las instançias devidas que se agan con él piadosamente, sin proçeder a muerte natural, flu[x]sión de sangre ni mutilaçión de mienbro. Y más le condenamos en perdimiento de todos sus bienes y haçienda, aplicándolos a la cámara y fisco real (Img. 150). 
Hem de tenir present que, per bé que la sentència instava les autoritats seglars que tractassen l'acusat de manera piadosa, fórmules d'aquest tipus eren habituals a les sentències que implicaven la pena capital. D’una banda, la Inquisició no executava directament ningú; en aquells casos en què l'acusació del fiscal era provada, l'acusat no se'n penedia del seu crim d'heretgia o d'atemptar contra els bons costums de l'Església catòlica, o era declarat relapse -això és, reincident-, el Sant Ofici podia relaxar l'acusat a la justícia reial. D'aquesta manera, el reu passava a la jurisdicció seglar i eren les autoritats civils, doncs, les encarregades d'executar la sentència que pertocava en aquests casos. Tant pel que fa als condemnats per heretgia com, en el cas que ens pertoca, pel crim de sodomia, la justícia seglar els hi administrava la mateixa condemna, la mort a la foguera.

D'altra banda, la formulació de la clàusula «sin proçeder a muerte natural», no ens ha de dur a engany. Relaxar el reu a la justícia seglar era un eufemisme, sinònim, doncs, de condemna a mort. Procedir a mort natural, normalment per estrangulament amb garrot vil, estava reservat per a aquells heretges condemnats a mort que, en última instància, s'havien confessat i penedit del seu crim, tot i que, pel motiu que fóra, la seua salvació no era possible. En aquests casos, morien per estrangulament i, després, eren cremats a la foguera per estalviar-los el patiment de morir cremats vius. Valga d'exemple el cas de Diego Díaz, condemnat al desterrament en un primer judici per, malgrat ser cristià batejat, observar la llei de Moisés. Després d'incomplir l'ordre de desterrament, va ser condemnat per judaitzant pertinaç:

devemos declarar y declaramos el dicho Diego Díaz haver sido y ser herege judaiçante, observante de la caduca y muerta ley de Moissén, apóstata fautor y encubridor de hereges [...] devemos de relajar y relajamos la persona del dicho Diego Díaz a la justicia y brazo seglar [...] a los quales rogamos y encargamos mui afectuosamente, como de derecho mejor podemos, se ayan benigna y piadossamente con él (AHN, Inquisición, 1729, Exp. 12: Img. 368-69).

El dia de l'auto de fe, els inquisidors van fer lectura pública de la següent sentència:

Que sea llevado por las calles públicas de esta ciudad, cavallero en una bestia de albarda y con voz de pregonero manifieste su delito [...] y en la parte y lugar que para esto está señalado, se queme en vivas llamas de fuego hasta que se combierta en çeniça y de él no quede memoria (AHN, Inquisición, 1729, Exp. 12: Img. 371).

Finalment, de camí al cremador Diego Díaz degué penedir-se del seu crim, perquè segons l'acta posterior:

Haviéndole puesto en un madero por el verdugo le fue dado garrote y su cuerpo quemado en vivas llamas (AHN, Inquisición, 1729, Exp. 12: Img. 372).

En canvi, a aquells que no es penedien dels seus crims, els esperava la mort per vivicombustió a la foguera. Del procés d'Amador de Molina no ens ha arribat cap fragment semblant a aquest darrer que explique què va passar el dia de l'auto de fe. Únicament conservem el següent document, que explica:

Dada y pronunciada fue la sentencia desuso contenida por los señores inquisidores, y en ella firmaron y ordinaron en auto público de la fe que se celebró en 19 de junio 1588 en la plaça de la Seo, dicha de los Apóstoles, estando en él los señores inquisidores arriba dichos y presentes el fiscal y el reo; y por testigos, don Juan Pardo de la Casta, don Grao Bou, señor de Millás, 
Jayme Bartolomeo, familiares, y otros muchos. Y d'ello doy fe, Nicolás del Rio, secretario [rúbricat] (Img. 150).

Recordem que la darrera declaració d'Amador de Molina es va efectuar el 18 de juny de 1588. La sentència definitiva s'hauria d'haver produït aquell mateix dia, atés que de manera precipitada, l'endemà mateix, Amador va ser relaxat a la justícia seglar en auto públic de la fe. No hem trobat, de moment, més documentació respecte aquest procés ni d'aquell auto de fe de 1588. No desestimem, però, que rebuscant entre relacions de causes, mèrits, alegacions, visites d'inquisidors generals a València i altre tipus de documentació inquisitorial, algun dia Amador de Molina torne a aparéixer en algun document que ens aporte més llum sobre el final d'aquest porter oriünd de Múrcia i resident a Ontinyent. Però tampoc no és agosarat suposar que, en aquell auto de fe del 19 de juny de 1588, després d'haver-li llegit la sentència, Amador hagués transitat els carrers de València des de la plaça de la Seu fins al riu Túria, on solia instalar-se el cremador, i acabés els seus dies cremat a la foguera pels únics delictes que pogueren provar-li, això és, el d'haver mantingut relacions sexuals amb altres homes. 
Jacob Mompó Navarro. El procés contra el mulat Amador de Molina per sodomia, del 1588

\section{Bibliografia}

Bazán, Iñaki (2007) «La construcción del discurso homofóbico en la Europa cristiana medieval», En la España Medieval, 30, pp. 433-454.

Berco, Cristian (2007) Sexual hirarchies, public status: Men, sodomy, and society in Spain's golden age. Toronto, University of Toronto Press.

Bennassar, Bartolomé (1984) Inquisición española. Poder político y control social. Barcelona, Crítica.

Blázquez Miguel, Juan (1988) La Inquisición. Madrid, Penthalón.

Carrasco, Rafael (1982) «Las torpezas nefandas», Debats, 2-3, pp. 32-39.

—_.(1985) «Herejía y sexualidad en el Siglo de Oro», Cuadernos del Norte, 6, pp. 62-72.

-.(1986) Inquisición y represión sexual en Valencia. Historia de los sodomitas (1565-1785). Barcelona, Laertes.

—_. (1987) «Marginalidad sexual e Inquisición en la Valencia moderna», dins Alonso Hernández (dir.) Marginalismos: Actas del $3^{\circ}$ Symposium de Groningen 15-17-X-1984. Gröningen, pp. 35-55.

Dotis Dolader, Miguel Ángel (2000) «Imago Dei deturpatur: El pecado "nefando" o "contra natura" en el Arzobispado de Zaragoza (Siglos XV-XVI)», Hispania Sacra, 52, 105, pp. 343-365.

Dufour, Gerard (1988) «Las ideas politico-religiosas de Juan Antonio Llorente», Cuadernos de Historia Contemporánea, 10, pp. 11-21.

Fernández, André (1997) «The repression of sexual behavior by the Aragonese Inquisition between 1560 and 1700», Journal of the History of Sexuality, 7, pp. 469-502.

Escudero López, José Antonio (1983) «Los orígenes del Consejo de la Suprema Inquisición», Anuario de historia del derecho español, 53, pp. 238-289.

—.(1986) «La Inquisición española», Historia 16, no Extra 1, pp. 5-14.

—. (1987) «Inquisición y estudios inquisitoriales», Cuenta y razón, 26, pp. 53-62.

—. (2005) Estudios sobre la Inquisición. Madrid, Marcial Pons.

Escudero, Jose Antonio \& Birckel, Maurice (2004) La Inquisición. Las Rozas, Dastin Export.

Fernández Giménez, M. del Camino (1999) «La Sentencia inquisitorial», Manuscrits, 17, pp. 119-140.

García Cárcel, Ricardo (1976) Orígenes de la Inquisición española. El Tribunal de Valencia, 1478-1530. Barcelona, Península.

——. (1980) Herejía y sociedad en el siglo ХИ. La Inquisición en Valencia, 1530-1609. Barcelona, Península.

—_. (1996) «Veinte años de historiografia de la Inquisición. Algunas reflexiones», dins Rafael Carrasco \& Ricardo García Cárcel \& Jaime Contreras (dirs.) La Inquisición y la sociedad española. València, Publicaciones de la Real Sociedad Económica de Amigos del País, pp. 31-56. 
—_. (1998) «La Inquisición en la Corona de Aragón», Revista de la Inquisición, 7, pp. 151-163.

- (1990) La Inquisición. Madrid, Anaya.

García Fuentes, Jose María (1982) «Inquisición y sexualidad en el Reino de Granada en el siglo XVI», Chronica Nova, 13, pp. 207-229.

Garrido i Valls, Josep-David (2016) «L'àrab i el català en contacte al migjorn valencià: el baix Vinalopó en el segle xv», La Rella, 29, pp. 115-140.

Garza Carvajal, Federico (2003) Butterflies wil burn: Prosecuting Sodomites in Early Modern Spain and Mexico. Texas, University of Texas Press.

Graullera Sanz, Vicente (1991). «El delito de sodomía en la Valencia del siglo XVI», Torrens, 7, pp. 213-246.

Haliczer, Stephen (1990) Inquisition and society in the Kingdom of Valencia, 1478-1834. Berkeley - Los Ángeles, University of California Press.

Kamen, Henry (1967) La Inquisición española. Barcelona: Grijalbo.

——. (1976) «Sexualidad e Inquisición», Historia 16, nº Extra 1, pp. 99-106.

- (1981) «Nuevas perspectivas sobre la Inquisición española», Nueva Revista de Filología Hispánica, 30, 2, pp. 666-669.

- (1993) The phoenix and the flame. Catalonia and the Counter Reformation. New Haven - London, Yale University Press.

—. (2005) La Inquisición española. Una revisión histórica. Barcelona, Crítica.

Labarta, Ana (1987) La onomástica de los moriscos valencianos. Madrid, CSIC.

Lea, Henry Charles (1906-1908) A bistory of the Inquisition of Spain. 4 vols. New York - London, The Macmillan Company.

Menéndez Pelayo, Marcelino (1880-1881) Historia de los heterodoxos españoles. 3 vols. Madrid, Librería Católica de San José.

Molina, Fernanda (2009) No digno de nombrar. Prácticas sexuales probibidas en el virreinato del Perú (siglos ХИІ-ХИІІ. Buenos Aires, Universidad de Buenos Aires. Tesi doctoral.

- (2010a) «Los sodomitas virreinales: entre sujetos jurídicos y especie», Anuario de Estudios Americanos, 67, 1, pp. 23-52.

—. (2010b) «La herejización de la sodomía en la sociedad moderna. Consideraciones teológicas y praxis inquisitorial», Hispania Sacra, LXII, pp. 539-562.

Monter, William. (1992) La otra Inquisición. Inquisición española en la Corona de Aragón, Navarra, el País Vasco y Sicilia. Barcelona, Crítica.

Navarro Martínez, Juan Pedro (2017) «Represión y uso socio-político de la sodomía en la Corona de Aragón en el siglo XVI», Mundo Histórico. Revista de Investigación, 1. pp. 133-171. 
Pérez Villanueva, Joaquín \& Escadell Bonet, Bartolomé (dir.) (1984) Historia de la Inquisición en España y América. 3 vols. Madrid, Biblioteca de Autores Cristianos - Centro de Estudios Inquisitoriales.

Pérez Villanueva, Joaquín (dir.) (1980) La Inquisición española. Nueva visión, nuevos horizontes. I Simposium Internacional sobre la Inquisición Española (Cuenca, 25-29 de septiembre de 1978). Madrid, Siglo XxI.

Peters, Edward (1988) Inquisition. Berkeley - Los Ángeles, University of California Press.

Pinto Crespo, Virgilio (1983) Inquisición y control ideológico en la España del siglo ХИ. Madrid, Taurus.

Riera i Sans, Jaume (2014) Sodomites catalans. Història i vida (segles XIII-XVIII). Barcelona, Editorial Base.

Rosselló, Ramon (1978) L’homosexualitat a Mallorca a l'edat mitjana. Barcelona, Ramon Rosselló i José J. de Olañeta.

Ruiz Astiz, Javier (2017) «"Meresce la pena ordinaria de muerte": Estudio de las denuncias por bestialismo en la Navarra del Antiguo Régimen», Chronica Nova, 43, pp. 299-333.

Testón Núñez, Isabel \& Hernández Bermejo, María Ángeles (1988) «La sexualidad prohibida y el Tribunal de la Inquisición de Llerena», a dins Revista de Estudios Extremeños, 44, 3, pp. 623-660.

Tomas y Valiente, Francisco (1990) «El crimen y pecado contra natura», Francisco Tomás y Valiente et al. (eds.), Sexo barroco y otras transgresiones premodernas. Madrid, Alianza Editorial, pp. 33-56.

Turberville, Arthur (1954) La Inquisición española. Mèxic, Fondo de Cultura Económica. 